\title{
LEVEL II SCOUR ANALYSIS FOR BRIDGE 23 (BRADTH00090023) on TOWN HIGHWAY 9, crossing MILL POND BROOK, BRADFORD, VERMONT
}

Open-File Report 98-195

Prepared in cooperation with

VERMONT AGENCY OF TRANSPORTATION

and

FEDERAL HIGHWAY ADMINISTRATION

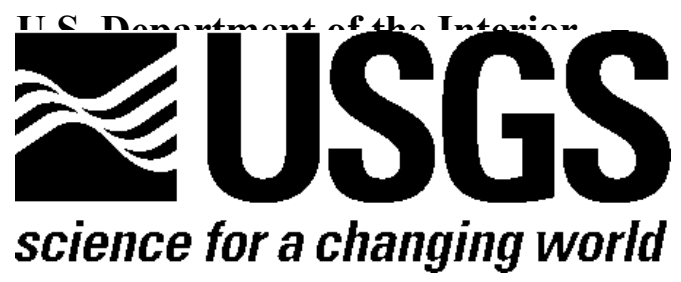




\section{LEVEL II SCOUR ANALYSIS FOR BRIDGE 23 (BRADTH00090023) on TOWN HIGHWAY 9, crossing MILL POND BROOK, BRADFORD, VERMONT}

By MICHAEL A. IVANOFF AND TIM SEVERANCE

U.S. Geological Survey Open-File Report 98-195

Prepared in cooperation with

VERMONT AGENCY OF TRANSPORTATION

and

FEDERAL HIGHWAY ADMINISTRATION 


\title{
U.S. DEPARTMENT OF THE INTERIOR BRUCE BABBITT, Secretary
}

\author{
U.S. GEOLOGICAL SURVEY
}

Thomas J. Casadevall, Acting Director

For additional information write to:

District Chief

U.S. Geological Survey 361 Commerce Way

Pembroke, NH 03275-3718
Copies of this report may be purchased from:

U.S. Geological Survey

Branch of Information Services

Open-File Reports Unit

Box 25286

Denver, CO 80225-0286 


\section{CONTENTS}

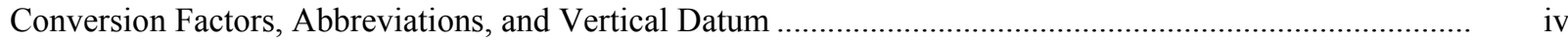

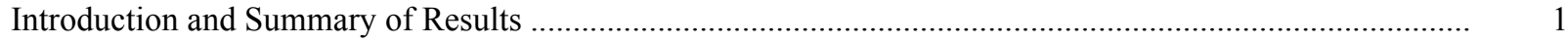

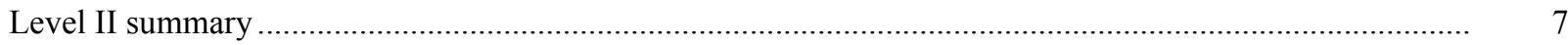

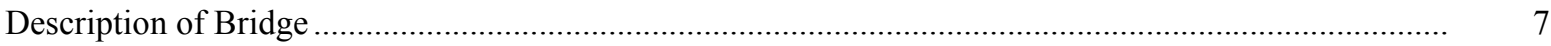

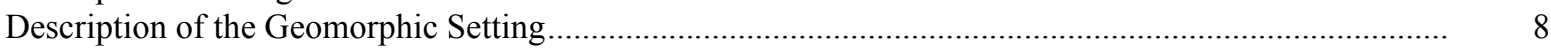

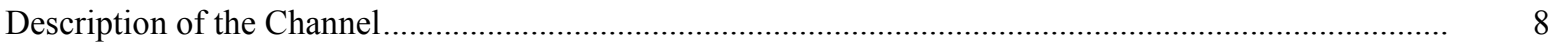

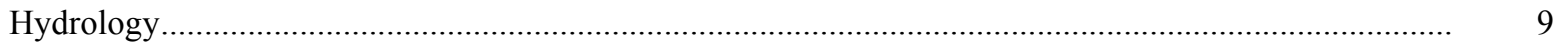

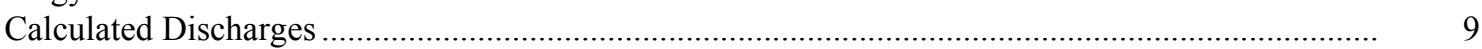

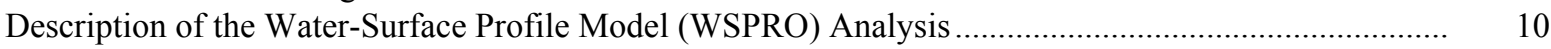

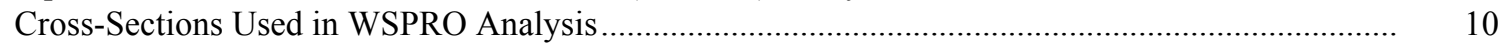

Data and Assumptions Used in WSPRO Model ........................................................................ 11

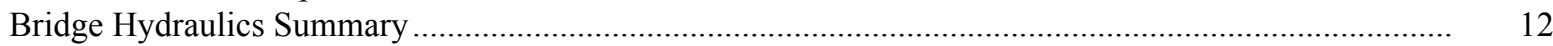

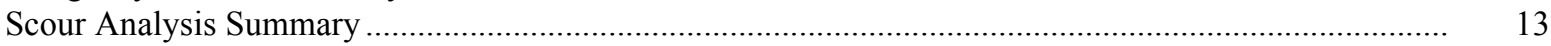

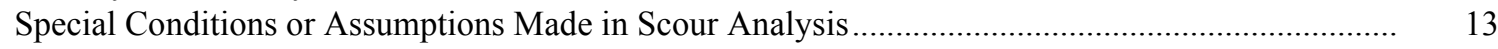

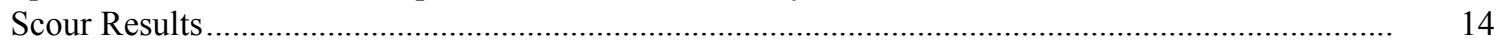

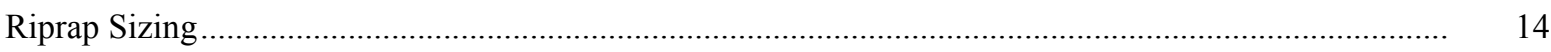

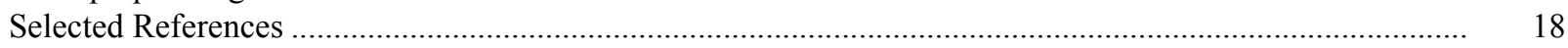

Appendices:

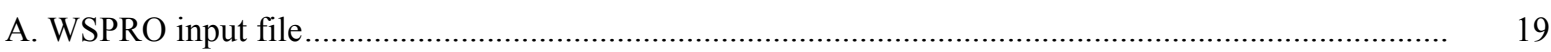

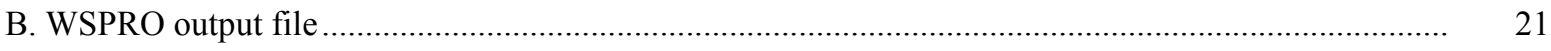

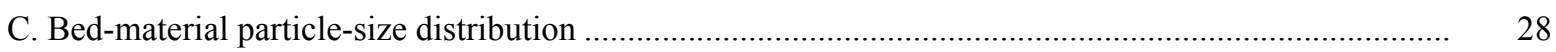

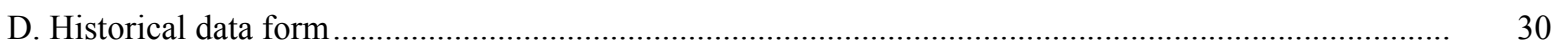

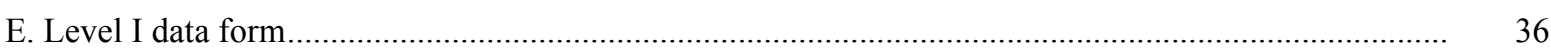

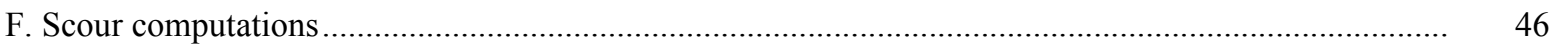

\section{FIGURES}

1. Map showing location of study area on USGS 1:24,000 scale map

2. Map showing location of study area on Vermont Agency of Transportation town highway map

3. Structure BRADTH00090023 viewed from upstream (September 7, 1995)

4. Downstream channel viewed from structure BRADTH00090023 (September 7, 1995).

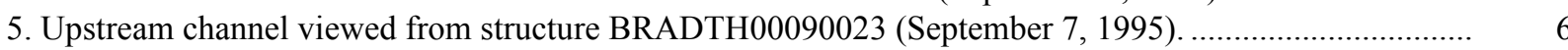

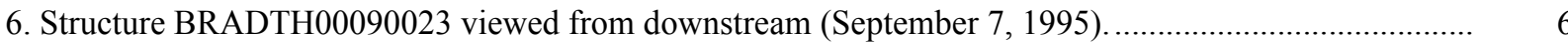

7. Water-surface profiles for the 100- and 500-year discharges at structure BRADTH00090023 on Town Highway 9, crossing Mill Pond Brook, Bradford, Vermont.

8. Scour elevations for the 100- and 500-year discharges at structure

BRADTH00090023 on Town Highway 9, crossing Mill Pond Brook,

Bradford, Vermont.

\section{TABLES}

1. Remaining footing/pile depth at abutments for the 100-year discharge at structure

BRADTH00090023 on Town Highway 9, crossing Mill Pond Brook,

Bradford, Vermont

2. Remaining footing/pile depth at abutments for the 500-year discharge at structure

BRADTH00090023 on Town Highway 9, crossing Mill Pond Brook,

Bradford, Vermont 


\begin{tabular}{|c|c|c|}
\hline Multiply & By & To obtain \\
\hline \multicolumn{3}{|c|}{ Length } \\
\hline inch (in.) & 25.4 & millimeter (mm) \\
\hline foot $(\mathrm{ft})$ & 0.3048 & meter $(\mathrm{m})$ \\
\hline mile (mi) & 1.609 & kilometer (km) \\
\hline \multicolumn{3}{|c|}{ Slope } \\
\hline foot per mile (ft/mi) & 0.1894 & meter per kilometer $(\mathrm{m} / \mathrm{km})$ \\
\hline \multicolumn{3}{|c|}{ Area } \\
\hline square mile $\left(\mathrm{mi}^{2}\right)$ & 2.590 & square kilometer $\left(\mathrm{km}^{2}\right)$ \\
\hline \multicolumn{3}{|c|}{ Volume } \\
\hline cubic foot $\left(\mathrm{ft}^{3}\right)$ & $\begin{array}{l}0.02832 \\
\text { Velocity and Flow }\end{array}$ & cubic meter $\left(\mathrm{m}^{3}\right)$ \\
\hline foot per second $(\mathrm{ft} / \mathrm{s})$ & 0.3048 & meter per second $(\mathrm{m} / \mathrm{s})$ \\
\hline cubic foot per second $\left(\mathrm{ft}^{3} / \mathrm{s}\right)$ & 0.02832 & cubic meter per second $\left(\mathrm{m}^{3} / \mathrm{s}\right.$ \\
\hline $\begin{array}{l}\text { cubic foot per second per } \\
\text { square mile } \\
{\left[\left(\mathrm{ft}^{3} / \mathrm{s}\right) / \mathrm{mi}^{2}\right]}\end{array}$ & 0.01093 & $\begin{array}{l}\text { cubic meter per } \\
\text { second per square } \\
\text { kilometer }\left[\left(\mathrm{m}^{3} / \mathrm{s}\right) / \mathrm{km}^{2}\right.\end{array}$ \\
\hline
\end{tabular}

\section{OTHER ABBREVIATIONS}

\begin{tabular}{|c|c|c|c|}
\hline $\mathrm{BF}$ & bank full & LWW & left wingwall \\
\hline $\mathrm{cfs}$ & cubic feet per second & Max & maximum \\
\hline $\mathrm{D}_{50}$ & median diameter of bed material & $\mathrm{MC}$ & main channel \\
\hline DS & downstream & RAB & right abutment \\
\hline elev. & elevation & RABUT & face of right abutment \\
\hline $\mathrm{f} / \mathrm{p}$ & flood plain & $\mathrm{RB}$ & right bank \\
\hline $\mathrm{ft}^{2}$ & square feet & ROB & right overbank \\
\hline $\mathrm{ft} / \mathrm{ft}$ & feet per foot & RWW & right wingwall \\
\hline FEMA & Federal Emergency Management Agency & $\mathrm{TH}$ & town highway \\
\hline FHWA & Federal Highway Administration & UB & under bridge \\
\hline JCT & junction & US & upstream \\
\hline LAB & left abutment & USGS & United States Geological Survey \\
\hline LABUT & face of left abutment & VTAOT & Vermont Agency of Transportation \\
\hline LB & left bank & WSPRO & water-surface profile model \\
\hline LOB & left overbank & yr & year \\
\hline
\end{tabular}

In this report, the words "right" and "left" refer to directions that would be reported by an observer facing downstream. Sea level: In this report, "sea level” refers to the National Geodetic Vertical Datum of 1929-- a geodetic datum derived from a general adjustment of the first-order level nets of the United States and Canada, formerly called Sea Level Datum of 1929.

In the appendices, the above abbreviations may be combined. For example, USLB would represent upstream left bank. 


\title{
LEVEL II SCOUR ANALYSIS FOR BRIDGE 23 (BRADTH00090023) ON TOWN HIGHWAY 9, CROSSING MILL POND BROOK, BRADFORD, VERMONT
}

\author{
By Michael A. Ivanoff and Tim Severance
}

\section{INTRODUCTION AND SUMMARY OF RESULTS}

This report provides the results of a detailed Level II analysis of scour potential at structure BRADTH00090023 on Town Highway 9 crossing Mill Pond Brook, Bradford, Vermont (figures 1-8). A Level II study is a basic engineering analysis of the site, including a quantitative analysis of stream stability and scour (FHWA, 1993). Results of a Level I scour investigation also are included in appendix E of this report. A Level I investigation provides a qualitative geomorphic characterization of the study site. Information on the bridge, gleaned from Vermont Agency of Transportation (VTAOT) files, was compiled prior to conducting Level I and Level II analyses and is found in appendix D.

The site is in the New England Upland section of the New England physiographic province in east-central Vermont. The 6.06- $\mathrm{mi}^{2}$ drainage area is in a predominantly rural and forested basin. In the vicinity of the study site, the surface cover consists of trees, brush, and grassy areas in a suburban setting. The downstream right bank is forested.

In the study area, Mill Pond Brook has an incised, sinuous channel with a slope of approximately $0.02 \mathrm{ft} / \mathrm{ft}$, an average channel top width of $42 \mathrm{ft}$ and an average bank height of $5 \mathrm{ft}$. The channel bed material ranges from gravel to boulders with a median grain size $\left(\mathrm{D}_{50}\right)$ of $52.4 \mathrm{~mm}(0.172 \mathrm{ft})$. The geomorphic assessment at the time of the Level I and Level II site visit on September 7, 1995, indicated that the reach was stable.

The Town Highway 9 crossing of Mill Pond Brook is a 33-ft-long, two-lane bridge consisting of one 29-foot concrete T-beam span (Vermont Agency of Transportation, written communication, March 23, 1995). The opening length of the structure parallel to the bridge face is $27.1 \mathrm{ft}$. The bridge is supported by vertical, "laid-up" stone abutments with concrete caps. The channel is skewed approximately 20 degrees to the opening while the computed opening-skew-to-roadway is 5 degrees.

A scour hole $0.5 \mathrm{ft}$ deeper than the mean thalweg depth was observed in the upstream channel during the Level I assessment. The only scour protection measure at the site was type- 2 stone fill (less than 36 inches diameter) at the upstream ends of the left and right abutments and at the downstream end of the right abutment. Additional details describing conditions at the site are included in the Level II Summary and appendices D and E. 
Scour depths and recommended rock rip-rap sizes were computed using the general guidelines described in Hydraulic Engineering Circular 18 (Richardson and Davis, 1995) for the 100- and 500-year discharges. In addition, the incipient roadway-overtopping discharge was determined and analyzed as another potential worst-case scour scenario. Total scour at a highway crossing is comprised of three components: 1) long-term streambed degradation; 2) contraction scour (due to accelerated flow caused by a reduction in flow area at a bridge) and; 3) local scour (caused by accelerated flow around piers and abutments). Total scour is the sum of the three components. Equations are available to compute depths for contraction and local scour and a summary of the results of these computations follows.

Contraction scour for all modelled flows ranged from 0.5 to $1.1 \mathrm{ft}$. The worst-case contraction scour occurred at the 500-year discharge. Left abutment scour ranged from 6.2 to $14.8 \mathrm{ft}$. The worst-case left abutment scour occurred at the 500-year discharge. Right abutment scour ranged from 5.3 to $8.1 \mathrm{ft}$. The worst-case right abutment scour occurred at the incipient roadway-overtopping discharge. Additional information on scour depths and depths to armoring are included in the section titled "Scour Results". Scoured-streambed elevations, based on the calculated scour depths, are presented in tables 1 and 2. A crosssection of the scour computed at the bridge is presented in figure 8. Scour depths were calculated assuming an infinite depth of erosive material and a homogeneous particle-size distribution.

It is generally accepted that the Froehlich equation (abutment scour) gives "excessively conservative estimates of scour depths" (Richardson and Davis, 1995, p. 46). Usually, computed scour depths are evaluated in combination with other information including (but not limited to) historical performance during flood events, the geomorphic stability assessment, existing scour protection measures, and the results of the hydraulic analyses. Therefore, scour depths adopted by VTAOT may differ from the computed values documented herein. 


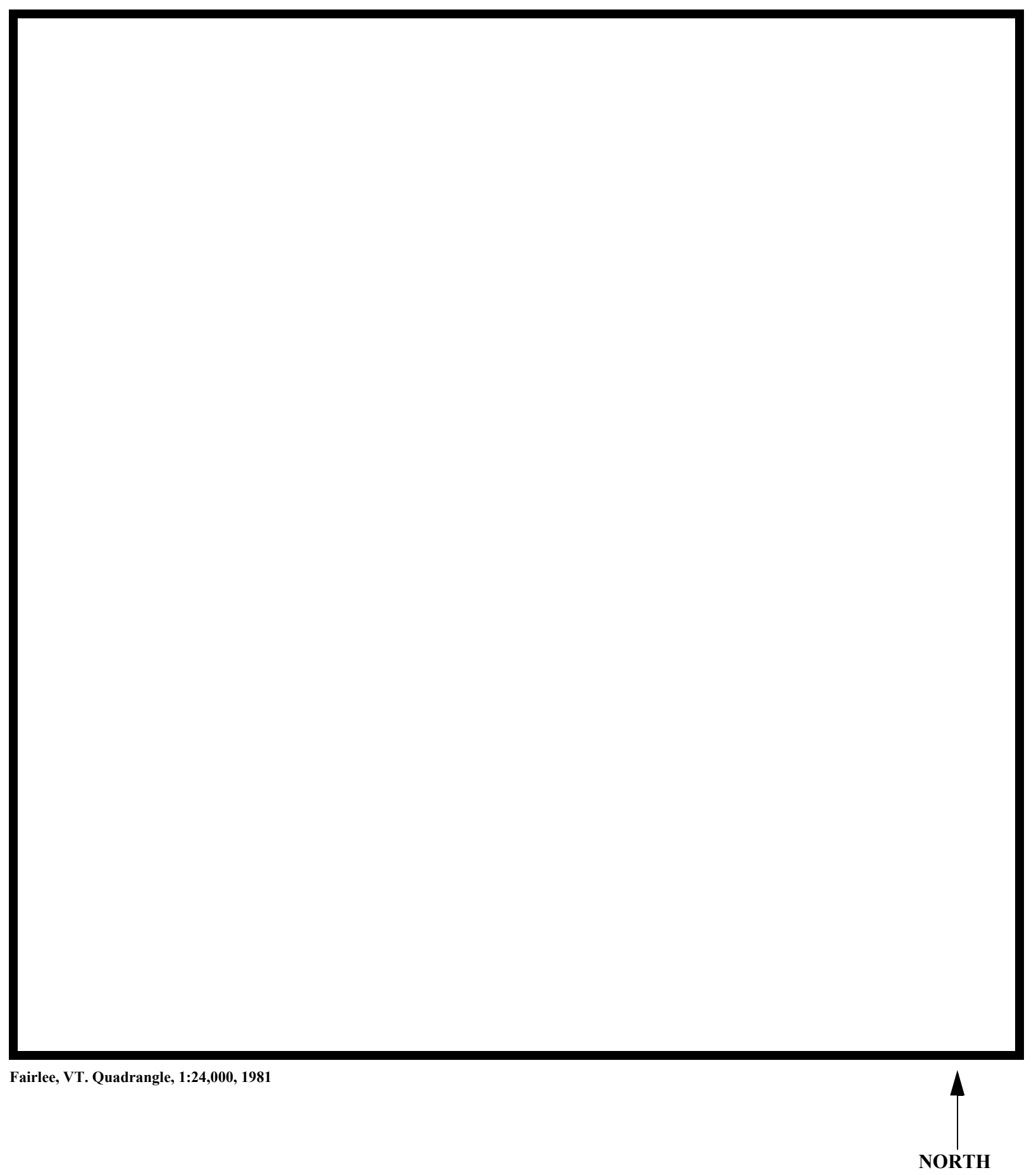

Figure 1. Location of study area on USGS 1:24,000 scale map. 
Figure 2. Location of study area on Vermont Agency of Transportation town highway map. 

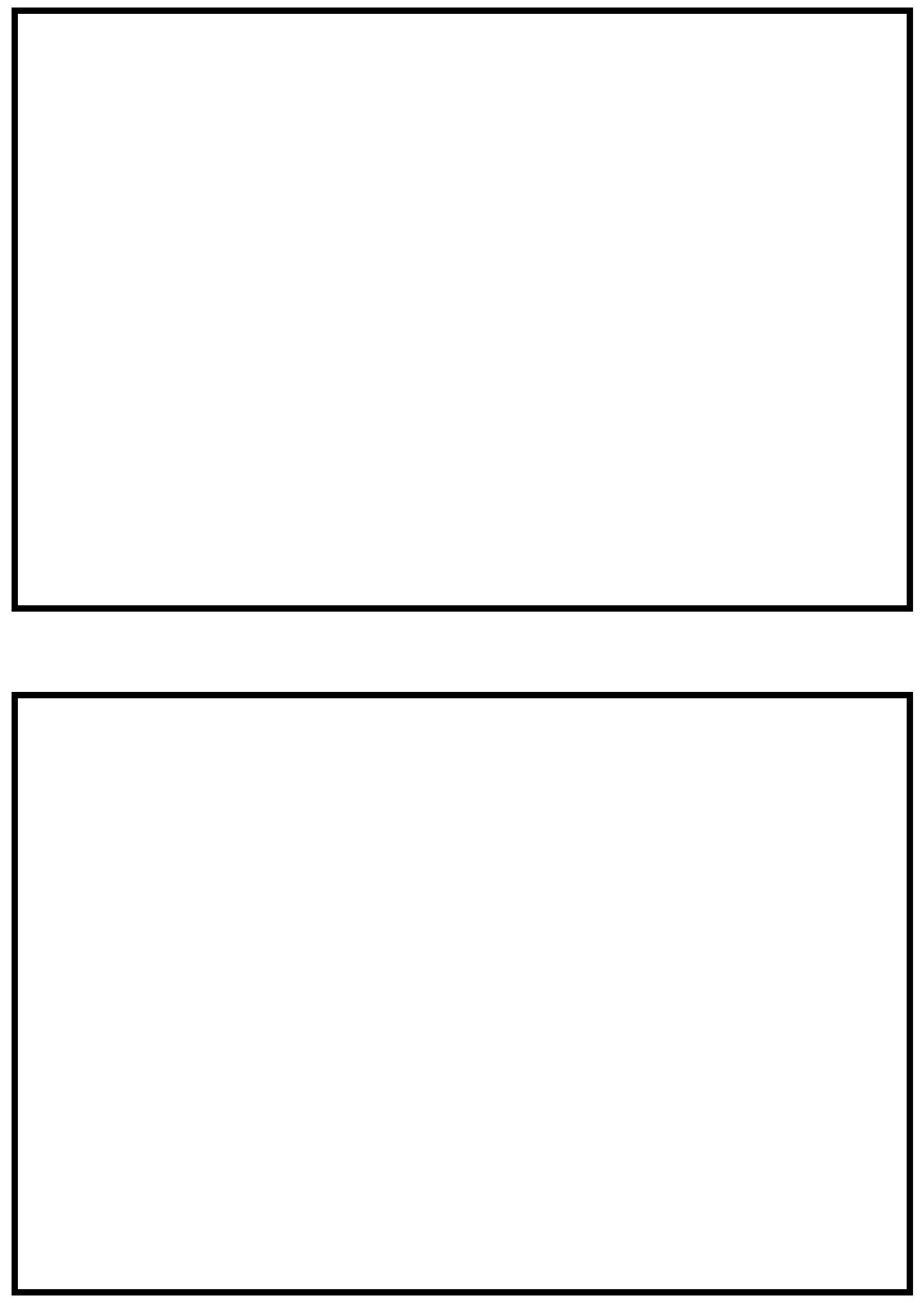

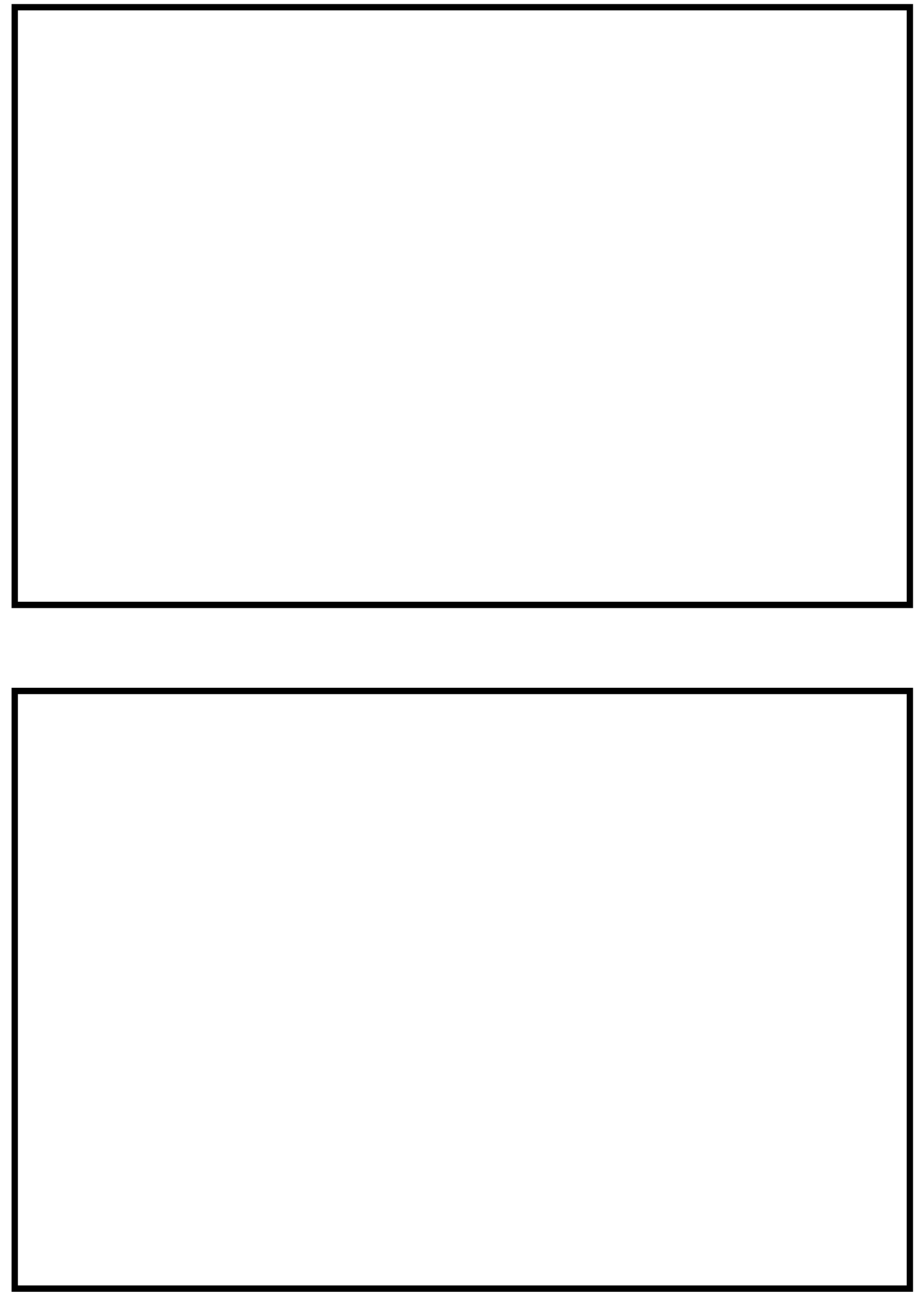


\section{LEVEL II SUMMARY}

\begin{tabular}{llllll} 
Structure Number & BRADTH00090023 & \multirow{3}{*}{ Stream } & \multicolumn{3}{c}{ Mill Pond Brook } \\
& Orange & Road & TH 9 & District & 7
\end{tabular}

\section{Description of Bridge}

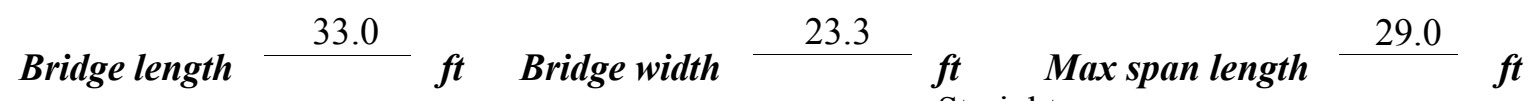

Alignment of bridge to road (on curve or straight)

Vertical, "laid-up" stone

Abutment type

Stone fill on abutment?

Yes

Embankment type

Straight

nomintinn of aton sill

Type-2, around the upstream and downstream ends of the right
Tymortinn

Sloping

9/7/95

abutment and at the upstream end of the left abutment.

Abutments are "laid-up" stone with concrete caps.

$\ldots \ldots \ldots$

Yes

20

Is bridge skewed to flood flow according to No ' survey? Angle

There is a mild channel bend in the upstream reach.

Debris accumulation on bridge at time of Level I or Level II site visit:

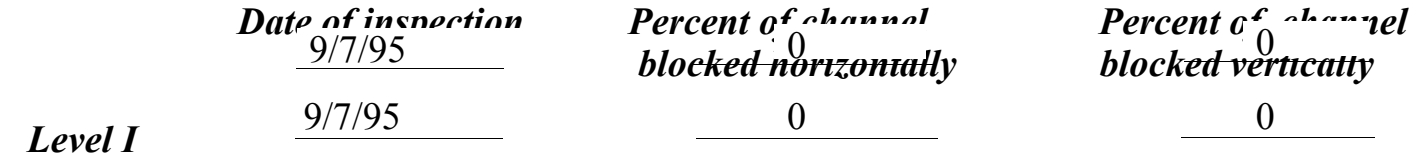

Level II

Moderate. There is some debris along the banks and trees are

leaning over the upstream channel.

Potential for debris

There is a short wall three feet high in front of the entire base length of the left abutment Doscriho anv fonturos noar ar at tho hridos that mav affort flow, (includo ohsorvation dato) protruding into the channel as of $9 / 7 / 95$. 


\section{Description of the Geomorphic Setting}

General topography The channel is located within a moderate relief valley with flat to slightly irregular narrow flood plains.

Geomorphic conditions at bridge site: downstream (DS), upstream (US)

Date of inspection $\quad 9 / 7 / 95$

DS left: $\quad$ Steep channel bank to a narrow flood plain.

DS right: $\quad$ Steep channel bank to a narrow flood plain.

US left: $\quad$ Steep channel bank to a moderately sloped overbank.

US right: Steep channel bank to a narrow flood plain.

\section{Description of the Channel}

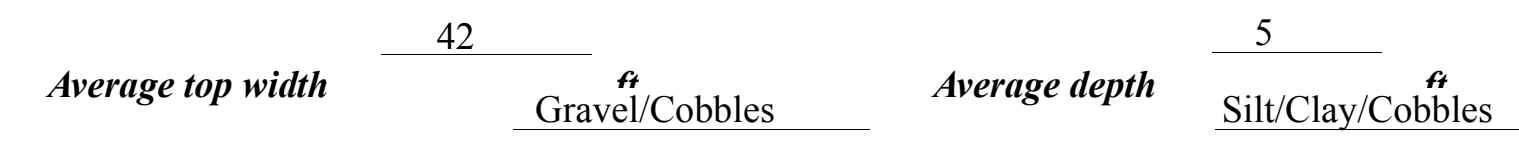

Predominant bed material Bank material Perennial and sinuous

but stable with semi-alluvial channel boundaries and narrow point $\ddot{\text { bars. }}$

$9 / 7 / 95$

Vegetative co 1 Short grass and brush with a feiw trees.

DS left: $\quad$ Trees and brush.

DS right: $\quad$ Trees and brush with grass on the overbank.

US left: $\quad$ Trees and brush with grass on the flood plain.

US right: $\quad$ Yes

Do banks appear stable? -

y mus, ме

date of observatton.

None, 9/7/95.

Describe any obstructions in channel and date of observation. 


\section{Hydrology}

Drainage area $\stackrel{6.06}{\boldsymbol{m i}^{2}}$

Percentage of drainage area in physiographic provinces: (approximate)

Physiographic province/section New England/New England Upland
Percent of drainage area 100

Is drainage area considered rural or urban? Rural Describe any significant

urbanization: There are a couple of houses on the overbank areas.

Is there a USGS gage on the stream of interest?

No

USGS gage description

USGS gage number

Gage drainage area $\mathrm{mi}^{2}$

No

Is there a lake/p -

\section{Calculated Discharges $\quad 1,830$ \\ 1,140 $f t^{3} / s$ \\ Q500 $\quad \mathrm{ft}^{3} / \mathrm{s}$}

The 100- and 500-year discharges are based on a

drainage area relationship.[(6.06/6.08) exp 0.67] with flood frequency estimates available for bridge number 4 in Bradford from the VTAOT database (written comm. May 1995). Bridge number 4 crosses Mill Pond Brook downstream of this site and has a drainage area of 6.08 square miles. The drainage area adjusted values were within a range defined by flood frequency curves developed from several empirical methods (Benson, 1962; Johnson and Tasker, 1974; FHWA, 1983; Potter, 1957a\&b; Talbot, 1887). Each curve was extended graphically to the 500year event. 


\section{Description of the Water-Surface Profile Model (WSPRO) Analysis}

Datum for WSPRO analysis (USGS survey, sea level, VTAOT plans)

USGS survey.

Datum tie between USGS survey and VTAOT plans

None.

Description of reference marks used to determine USGS datum. $\quad$ RM1 is a chiseled X on

top of the DS end of the right abutment (elev. $499.72 \mathrm{ft}$, arbitrary survey datum). RM2 is a

chiseled X on top of the US end of the left abutment (elev. $500.50 \mathrm{ft}$, arbitrary survey datum).

$\mathrm{RM} 3$ is a nail $4 \mathrm{ft}$ from the base of a power pole (CVPS 25T, 43-183-41) $44 \mathrm{ft}$ right bankward of

the DS end of the RABUT (500.28 ft, arbitrary survey datum).

\section{Cross-Sections Used in WSPRO Analysis}

\begin{tabular}{cccl}
\hline${ }^{1}$ Cross-section & $\begin{array}{c}\text { Section } \\
\text { Reference } \\
\text { Distance } \\
\text { (SRD) in feet }\end{array}$ & $\begin{array}{c}{ }^{2} \text { Cross-section } \\
\text { development }\end{array}$ & \multicolumn{1}{c}{ Comments } \\
\hline EXITX & -23 & 1 & Exit section \\
FULLV & 0 & 2 & $\begin{array}{l}\text { Downstream Full-valley } \\
\text { section (Templated from } \\
\text { EXITX) }\end{array}$ \\
BRIDG & 0 & 1 & Bridge section \\
RDWAY & 14 & 1 & Road Grade section \\
APPRO & 56 & 1 & Approach section \\
\hline
\end{tabular}

${ }^{1}$ For location of cross-sections see plan-view sketch included with Level I field form, Appendix E. For more detail on how cross-sections were developed see WSPRO input file. 


\section{Data and Assumptions Used in WSPRO Model}

Hydraulic analyses of the reach were done by use of the Federal Highway Administration's WSPRO step-backwater computer program (Shearman and others, 1986, and Shearman, 1990). The analyses reported herein reflect conditions existing at the site at the time of the study. Furthermore, in the development of the model it was necessary to assume no accumulation of debris or ice at the site. Results of the hydraulic model are presented in the Bridge Hydraulic Summary, appendix B, and figure 7.

Channel roughness factors (Manning's " $n$ ") used in the hydraulic model were estimated using field inspections at each cross section following the general guidelines described by Arcement and Schneider (1989). Final adjustments to the values were made during the modelling of the reach. Channel " $\mathrm{n}$ " values for the reach ranged from 0.050 to 0.070 , and overbank " $\mathrm{n}$ " values ranged from 0.035 to 0.065 .

Normal depth at the exit section (EXITX) was assumed as the starting water surface. This depth was computed by use of the slope-conveyance method outlined in the user's manual for WSPRO (Shearman, 1990). The slope used was $0.0214 \mathrm{ft} / \mathrm{ft}$, which was estimated from surveyed thalweg points downstream of the bridge.

The approach section (APPRO) was surveyed one bridge length upstream of the upstream face as recommended by Shearman and others (1986). This location provides a consistent method for determining scour variables.

For the 100-year discharge, WSPRO assumes critical depth at the bridge section. A supercritical model was developed for this discharge. After analyzing both the supercritical and subcritical profiles, it can be determined that the water surface profile does pass through critical depth within the bridge opening. Thus, the assumption of critical depth at the bridge is a satisfactory solution. 


\section{Bridge Hydraulics Summary}

$\begin{array}{llll}\text { Average bridge embankment elevation } & 500.4 & f t \\ \text { Average low steel elevation } & 497.7 & \boldsymbol{f t}\end{array}$

100-year discharge $\quad 1,140 \quad \mathrm{ft}^{3} / \mathrm{s}$

Water-surface elevation in bridge opening $\quad 495.3 \mathrm{ft}$

Road overtopping? ___ No Discharge over road ___-- $\mathrm{ft}^{3} / \mathrm{s}$

Area of flow in bridge opening $\quad 102 \quad \mathrm{ft}^{2}$

Average velocity in bridge opening $11.2 \mathrm{ft} / \mathrm{s}$

Maximum WSPRO tube velocity at bridge $\quad 14.4 \mathrm{ft} / \mathrm{s}$

Water-surface elevation at Approach section with bridge 498.0

Water-surface elevation at Approach section without bridge $\quad 496.0$

Amount of backwater caused by bridge

$2.0 \quad i$

500-year discharge $\quad 1,830 \quad \mathrm{ft}^{3} / \mathrm{s}$

Water-surface elevation in bridge opening

$497.7 \boldsymbol{f t}$

Road overtopping? ___ Yes Discharge over road __ $338 \quad \mathrm{ft}^{3} / \mathrm{s}$

Area of flow in bridge opening $\quad 164 \quad \mathrm{ft}^{2}$

Average velocity in bridge opening $\quad 9.1 \mathrm{ft} / \mathrm{s}$

Maximum WSPRO tube velocity at bridge 13.0 's

Water-surface elevation at Approach section with bridge 500.2

Water-surface elevation at Approach section without bridge $\quad 497.4$

Amount of backwater caused by bridge $\quad 2.8$.t

Incipient overtopping discharge $\quad 1,400 \quad \mathrm{ft}^{3} / \mathrm{s}$

Water-surface elevation in bridge opening $498.2 \quad t$

Area of flow in bridge opening $\quad \begin{array}{lll} & \mathrm{ft}^{2}\end{array}$

Average velocity in bridge opening $\quad 8.4 \quad \mathrm{ft} / \mathrm{s}$

Maximum WSPRO tube velocity at bridge $\quad 10.5 \mathrm{ft} / \mathrm{s}$

Water-surface elevation at Approach section with bridge

Water-surface elevation at Approach section without bridge

499.7

Amount of backwater caused by bridge $\quad 3.1$ it

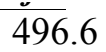




\section{Scour Analysis Summary}

\section{Special Conditions or Assumptions Made in Scour Analysis}

Scour depths were computed using the general guidelines described in Hydraulic Engineering Circular 18 (Richardson and Davis, 1995). Scour depths were calculated assuming an infinite depth of erosive material and a homogeneous particle-size distribution. The results of the scour analyses for the 100- and 500-year discharges are presented in tables 1 and 2 and the scour depths are shown graphically in figure 8 .

Contraction scour for the 100-year discharge was computed by use of the Laursen clear-water contraction scour equation (Richardson and Davis, 1995, p. 32, equation 20). At this site, the 500-year and incipient roadway-overtopping discharges resulted in unsubmerged orifice flow. Contraction scour at bridges with orifice flow is best estimated by use of the Chang pressure-flow scour equation (oral communication, J. Sterling Jones, October 4, 1996). Thus, contraction scour for these discharges was computed by use of the Chang equation (Richardson and Davis, 1995, p. 145-146). The streambed armoring depths computed suggest that armoring will not limit the depth of contraction scour.

For comparison, contraction scour for the discharges resulting in orifice flow was also computed by use of the Laursen clear-water contraction scour equation and the Umbrell pressure-flow equation (Richardson and Davis, 1995, p. 144). Furthermore, for those discharges resulting in unsubmerged orifice flow, contraction scour was computed by substituting estimates for the depth of flow at the downstream bridge face in the contraction scour equations. Results with respect to these alternate computations are provided in appendix F.

Abutment scour was computed by use of the Froehlich equation (Richardson and Davis, 1995, p. 48, equation 28). Variables for the Froehlich equation include the Froude number of the flow approaching the embankments, the length of the embankment blocking flow, and the depth of flow approaching the embankment less any roadway overtopping. 


\section{Scour Results}

Contraction scour:

Main channel

Live-bed scour

Clear-water scour

Depth to armoring

Left overbank

Right overbank

Local scour:

Abutment scour

Left abutment

Right abutment

Pier scour

Pier 1

Pier 2

Pier 3 100-year
discharge 500-year discharge

(Scour depths in feet)

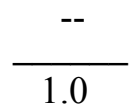

$$
20.8^{-}
$$
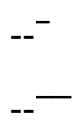

6.2

$7.8-$

14.8

5.3-

8.1-
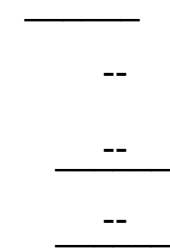

Incipient overtopping discharge 


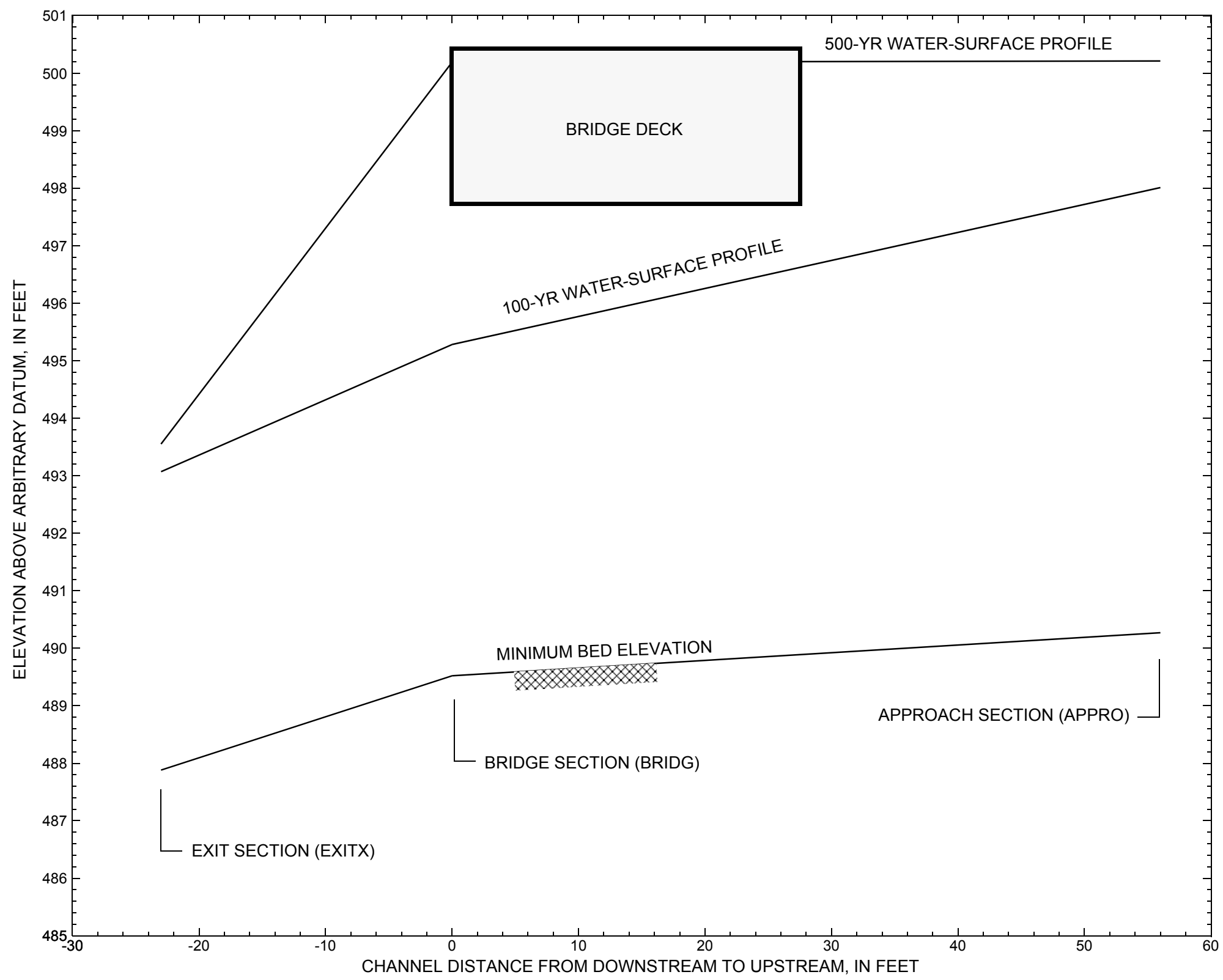

Figure 7. Water-surface profiles for the 100- and 500-year discharges at structure BRADTH00090023 on Town Highway 9, crossing Mill Pond Brook, Bradford, Vermont. 


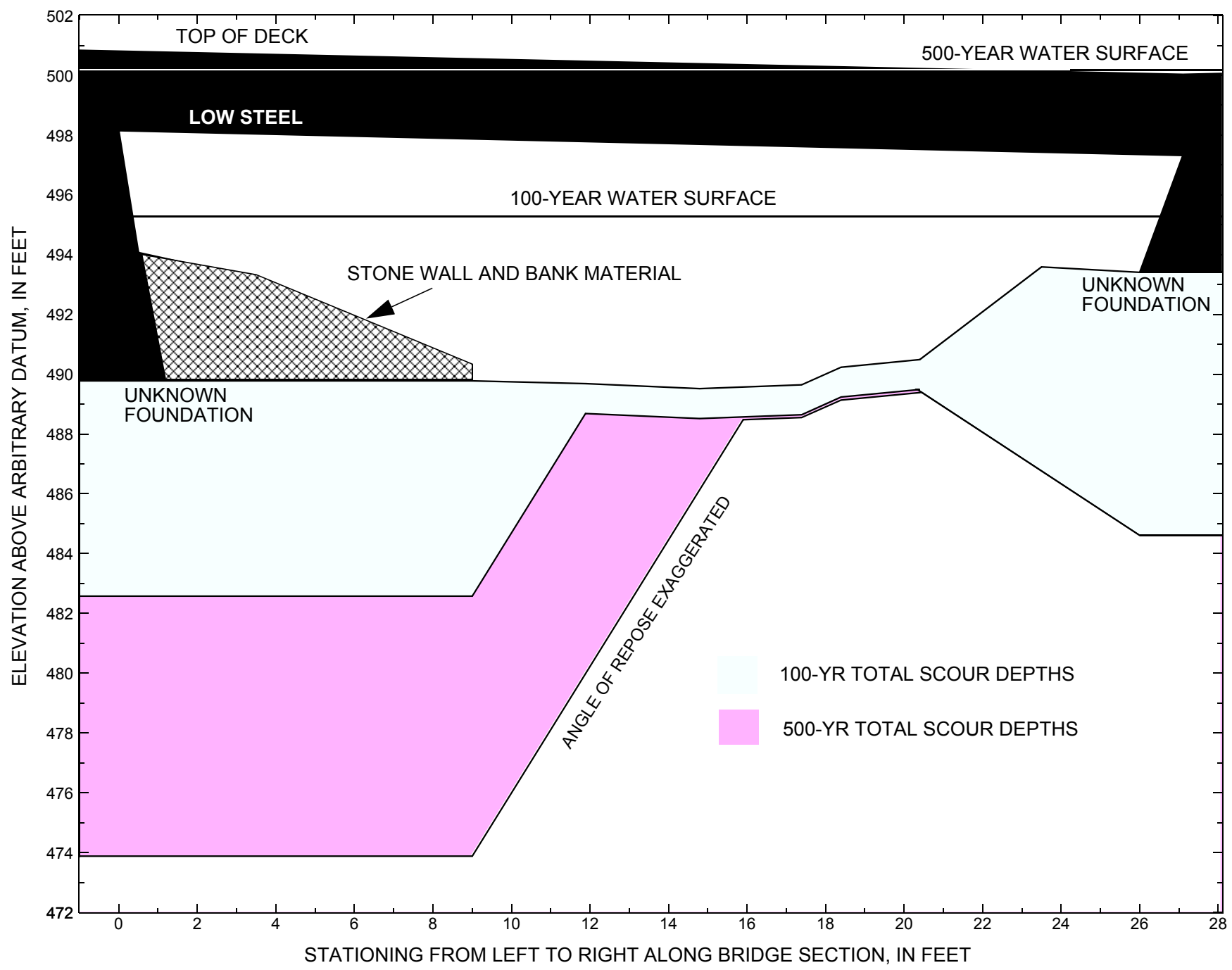

Figure 8. Scour elevations for the 100- and 500-year discharges at structure BRADTH00090023 on Town Highway 9, crossing Mill Pond Brook, Bradford, Vermont. 
Table 1. Remaining footing/pile depth at abutments for the 100-year discharge at structure BRADTH00090023 on Town Highway 9, crossing Mill Pond Brook, Bradford, Vermont.

[VTAOT, Vermont Agency of Transportation; --, no data]

\begin{tabular}{|c|c|c|c|c|c|c|c|c|c|c|c|}
\hline Description & Station $^{1}$ & $\begin{array}{l}\text { VTAOT } \\
\text { minimum } \\
\text { low-chord } \\
\text { elevation } \\
\text { (feet) }\end{array}$ & $\begin{array}{l}\text { Surveyed } \\
\text { minimum } \\
\text { low-chord } \\
\text { elevation } \\
\quad \text { (feet) }\end{array}$ & $\begin{array}{c}\text { Bottom of } \\
\text { footing/pile } \\
\text { elevation }{ }^{2} \\
\text { (feet) }\end{array}$ & $\begin{array}{c}\text { Channel } \\
\text { elevation at } \\
\text { abutment/ } \\
\text { pier }^{2} \\
\text { (feet) }\end{array}$ & $\begin{array}{l}\text { Contraction } \\
\text { scour depth } \\
\text { (feet) }\end{array}$ & $\begin{array}{l}\text { Abutment } \\
\text { scour } \\
\text { depth } \\
\text { (feet) }\end{array}$ & $\begin{array}{l}\text { Pier } \\
\text { scour } \\
\text { depth } \\
\text { (feet) }\end{array}$ & $\begin{array}{l}\text { Depth of } \\
\text { total scour } \\
\text { (feet) }\end{array}$ & $\begin{array}{c}\text { Elevation of } \\
\text { scour }^{2} \\
\text { (feet) }\end{array}$ & $\begin{array}{c}\text { Remaining } \\
\text { footing/pile } \\
\text { depth } \\
\text { (feet) }\end{array}$ \\
\hline \multicolumn{12}{|c|}{100 -year discharge is 1,140 cubic-feet per second } \\
\hline Left abutment & 0.0 & -- & 498.2 & -- & 489.8 & 1.0 & 6.2 & -- & 7.2 & 482.6 & -- \\
\hline Right abutment & 27.1 & -- & 497.3 & -- & 493.4 & 1.0 & 7.8 & -- & 8.8 & 484.6 & -- \\
\hline
\end{tabular}

1.Measured along the face of the most constricting side of the bridge.

2.Arbitrary datum for this study.

Table 2. Remaining footing/pile depth at abutments for the 500-year discharge at structure BRADTH00090023 on Town Highway 9, crossing Mill Pond Brook, Bradford, Vermont.

[VTAOT, Vermont Agency of Transportation; --, no data]

\begin{tabular}{|c|c|c|c|c|c|c|c|c|c|c|c|}
\hline Description & Station $^{1}$ & $\begin{array}{l}\text { VTAOT } \\
\text { minimum } \\
\text { low-chord } \\
\text { elevation } \\
\text { (feet) }\end{array}$ & $\begin{array}{c}\text { Surveyed } \\
\text { minimum } \\
\text { low-chord } \\
\text { elevation } \\
\text { (feet) }\end{array}$ & $\begin{array}{c}\text { Bottom of } \\
\text { footing/pile } \\
\text { elevation } \\
\text { (feet) }\end{array}$ & $\begin{array}{c}\text { Channel } \\
\text { elevation at } \\
\text { abutment/ } \\
\text { pier }^{2} \\
\text { (feet) }\end{array}$ & $\begin{array}{l}\text { Contraction } \\
\text { scour depth } \\
\text { (feet) }\end{array}$ & $\begin{array}{c}\text { Abutment } \\
\text { scour } \\
\text { depth } \\
\text { (feet) }\end{array}$ & $\begin{array}{l}\text { Pier } \\
\text { scour } \\
\text { depth } \\
\text { (feet) }\end{array}$ & $\begin{array}{l}\text { Depth of } \\
\text { total scour } \\
\text { (feet) }\end{array}$ & $\begin{array}{c}\text { Elevation of } \\
\text { scour }^{2} \\
\text { (feet) }\end{array}$ & $\begin{array}{c}\text { Remaining } \\
\text { footing/pile } \\
\text { depth } \\
\text { (feet) }\end{array}$ \\
\hline \multicolumn{12}{|c|}{500 -year discharge is 1,830 cubic-feet per second } \\
\hline Left abutment & 0.0 & -- & 498.2 & -- & 489.8 & 1.1 & 14.8 & -- & 15.9 & 473.9 & -- \\
\hline Right abutment & 27.1 & -- & 497.3 & -- & 493.4 & 1.1 & 5.3 & -- & 6.4 & 487.0 & -- \\
\hline
\end{tabular}

1.Measured along the face of the most constricting side of the bridge.

2.Arbitrary datum for this study. 


\section{SELECTED REFERENCES}

Arcement, G.J., Jr., and Schneider, V.R., 1989, Guide for selecting Manning's roughness coefficients for natural channels and flood plains: U.S. Geological Survey Water-Supply Paper 2339, 38 p.

Barnes, H.H., Jr., 1967, Roughness characteristics of natural channels: U.S. Geological Survey Water-Supply Paper 1849,213 p.

Benson, M. A., 1962, Factors Influencing the Occurrence of Floods in a Humid Region of Diverse Terrain: U.S. Geological Survey WaterSupply Paper 1580-B, 64 p.

Brown, S.A. and Clyde, E.S., 1989, Design of riprap revetment: Federal Highway Administration Hydraulic Engineering Circular No. 11, Publication FHWA-IP-89-016, 156 p.

Federal Highway Administration, 1983, Runoff estimates for small watersheds and development of sound design: Federal Highway Administration Report FHWA-RD-77-158.

Federal Highway Administration, 1993, Stream Stability and Scour at Highway Bridges: Participant Workbook: Federal Highway Administration Report FHWA-HI-91-011.

Froehlich, D.C., 1989, Local scour at bridge abutments in Ports, M.A., ed., Hydraulic Engineering--Proceedings of the 1989 National Conference on Hydraulic Engineering: New York, American Society of Civil Engineers, p. 13-18.

Hayes, D.C.,1993, Site selection and collection of bridge-scour data in Delaware, Maryland, and Virginia: U.S. Geological Survey WaterResources Investigation Report 93-4017, 23 p.

Interagency Advisory Committee on Water Data, 1982, Guidelines for determining flood flow frequency: U.S. Geological Survey, Bulletin 17B of the Hydrology Subcommittee, 190 p.

Johnson, C.G. and Tasker, G.D.,1974, Progress report on flood magnitude and frequency of Vermont streams: U.S. Geological Survey OpenFile Report 74-130, 37 p.

Lagasse, P.F., Schall, J.D., Johnson, F., Richardson, E.V., Chang, F., 1995, Stream Stability at Highway Structures: Federal Highway Administration Hydraulic Engineering Circular No. 20, Publication FHWA-IP-90-014, 144 p.

Laursen, E.M., 1960, Scour at bridge crossings: Journal of the Hydraulics Division, American Society of Civil Engineers, v. 86, no. HY2, p. 39-53.

Potter, W. D., 1957a, Peak rates of runoff in the Adirondack, White Mountains, and Maine woods area, Bureau of Public Roads

Potter, W. D., 1957b, Peak rates of runoff in the New England Hill and Lowland area, Bureau of Public Roads

Richardson, E.V. and Davis, S.R., 1995, Evaluating scour at bridges: Federal Highway Administration Hydraulic Engineering Circular No. 18, Publication FHWA-IP-90-017, 204 p.

Richardson, E.V., Simons, D.B., and Julien, P.Y., 1990, Highways in the river environment: Federal Highway Administration Publication FHWA-HI-90-016.

Ritter, D.F., 1984, Process Geomorphology: W.C. Brown Co., Debuque, Iowa, 603 p.

Shearman, J.O., 1990, User's manual for WSPRO--a computer model for water surface profile computations: Federal Highway Administration Publication FHWA-IP-89-027, 187 p.

Shearman, J.O., Kirby, W.H., Schneider, V.R., and Flippo, H.N., 1986, Bridge waterways analysis model; research report: Federal Highway Administration Publication FHWA-RD-86-108, 112 p.

Talbot, A.N., 1887, The determination of water-way for bridges and culverts.

U.S. Geological Survey, 1981, Fairlee, Vermont 7.5 Minute Series quadrangle map: U.S. Geological Survey Topographic Maps, Scale $1: 24,000$. 


\section{APPENDIX A: \\ WSPRO INPUT FILE}




\section{WSPRO INPUT FILE}

$\mathrm{Q}$

SK

*

XS

GR

GR

GR

GR

GR

GR

GR

$\mathrm{N}$

SA

*

XS

$\mathrm{BR}$

GR

GR

GR

GR

$\mathrm{CD}$

$\mathrm{N}$

*

*

$\mathrm{XR}$

GR

GR

GR

*

AS

GR

GR

GR

GR

GR

GR

$\mathrm{N}$

SA

HP 1 BRIDG

HP 2 BRIDG

HP 1 APPRO

HP 2 APPRO

HP 1 BRIDG

HP 2 BRIDG

HP 1 BRIDG

FULLV

RDWAY
U.S. Geological Survey WSPRO Input File brad023.wsp

Hydraulic analysis for structure BRADTH00090023 Date: 13-AUG-97

Bridge 23 on Town Highway 9 over Mill Pond Brook, Bradford, VT by MAI

* * 0.005

$\begin{array}{lllllllllllllllllllll}6 & 29 & 30 & 552 & 553 & 551 & 5 & 16 & 17 & 13 & 3 & * & 15 & 14 & 23 & 21 & 11 & 12 & 4 & 7 & 3\end{array}$

$1140.0 \quad 1830.0 \quad 1400.0$

$0.0214 \quad 0.0214 \quad 0.0214$

EXITX -23

$-181.7,509.36-154.6,506.55$

$-91.3,491.28 \quad-52.9,492.67$

$-128.4,500.97$

$-112.0,499.08$

$5.3,489.47$

$11.7,488.96$

$-14.7,492.72$

$0.0,492.30$

$14.0,488.53$

$14.3,487.88$

$28.4,490.47$

$22.6,489.97$

$90.7,493.83$

$33.0,492.92$

$42.4,492.21$

$81.3,491.75$

$138.0,497.64$

$177.4,497.91$

$\begin{array}{lll}111.5,494.70 & 123.5,497.42 \\ 209.0,497.39 & 258.3,497.80\end{array}$

$303.0,497.85$

$316.3,502.98$

$0.0 \quad 33.0$

0.065

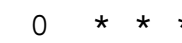

0.0324

\section{SRD}

\section{LSEL}

XSSKEW

$\begin{array}{cc}0 & 497.74 \\ 0.0, & 498.15\end{array}$

$$
5.0
$$

$9.0,489.78$

$0.5,494.07$

$3.5,493.21$

$14.8,489.52$

$8.9,490.28$

$11.9,489.69$

$23.5,493.59$

$17.4,489.65$

$20.4,490.49$

$0.0,498.15$

$27.1,497.32$

BRTYPE BRWDTH

$\begin{array}{ll}1 & 27.5\end{array}$

0.05

SRD

EMBWID

23.3

$-268.4,519.02$

$0.0,500.81$

$146.6,499.51$
$148.9,506.60$
$28.6,500.03$

$-112.8,504.20$

$-45.8,501.92$

$45.2,499.67$

$107.3,499.54$

$287.0,502.98$

$-145.6,503.85$

$-7.8,497.53$

$7.5,490.60$

$18.4,491.56$

$70.3,499.54$

$-111.5, \quad 501.44$

$4.7,490.84$

$14.8,490.73$

$43.5,499.36$

$35.8,497.94$

$250.0,502.98$

0.035

0.065

0.045

$-7.8$

43.5

495.281495 .28

495.28 * 1140

498.011498 .01

$498.01 * * 1140$

$497.74 \quad 1 \quad 497.74$

497.74 * * 1498

496.081496 .08 


\section{APPENDIX B: \\ WSPRO OUTPUT FILE}


WSPRO OUTPUT FILE

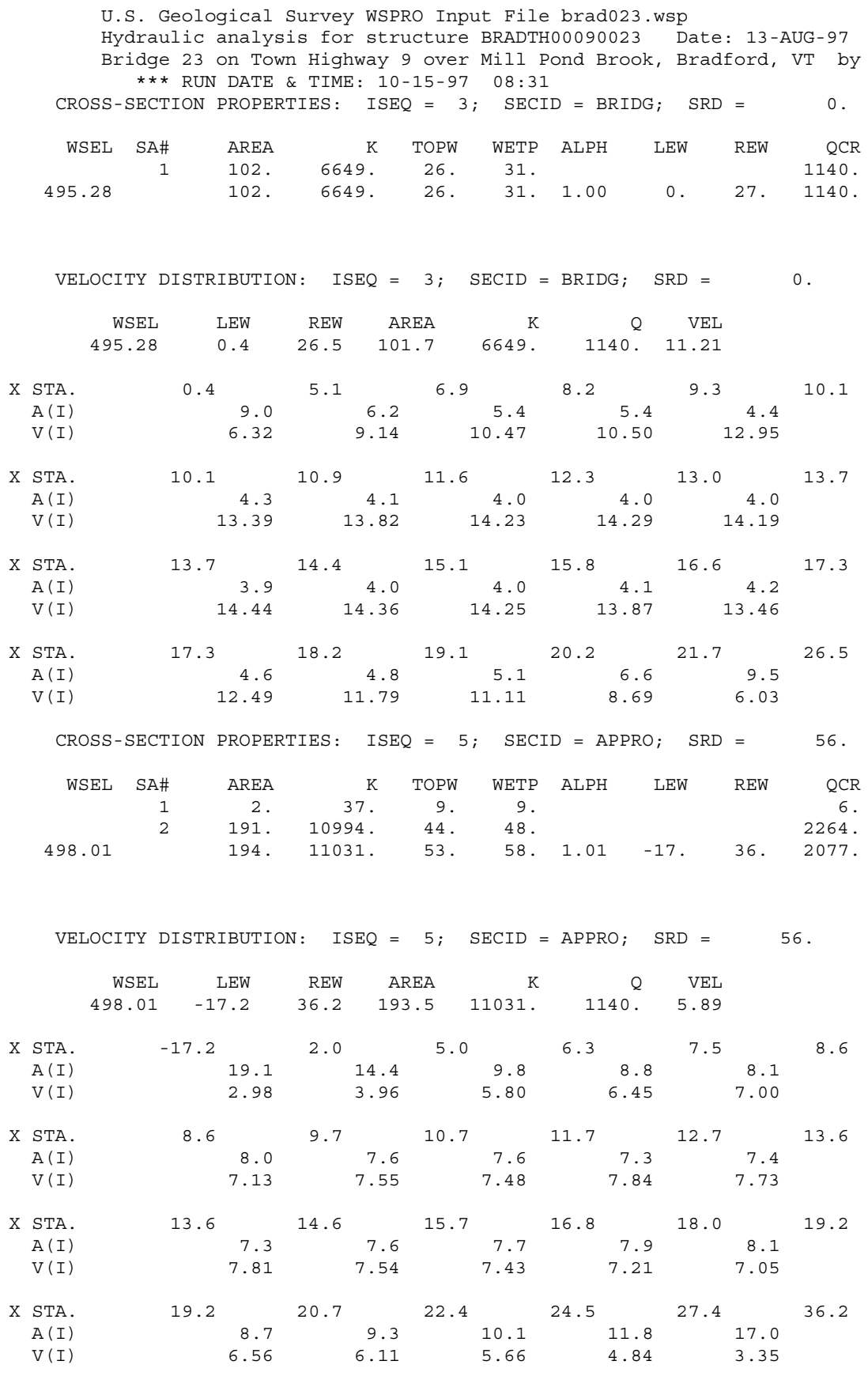




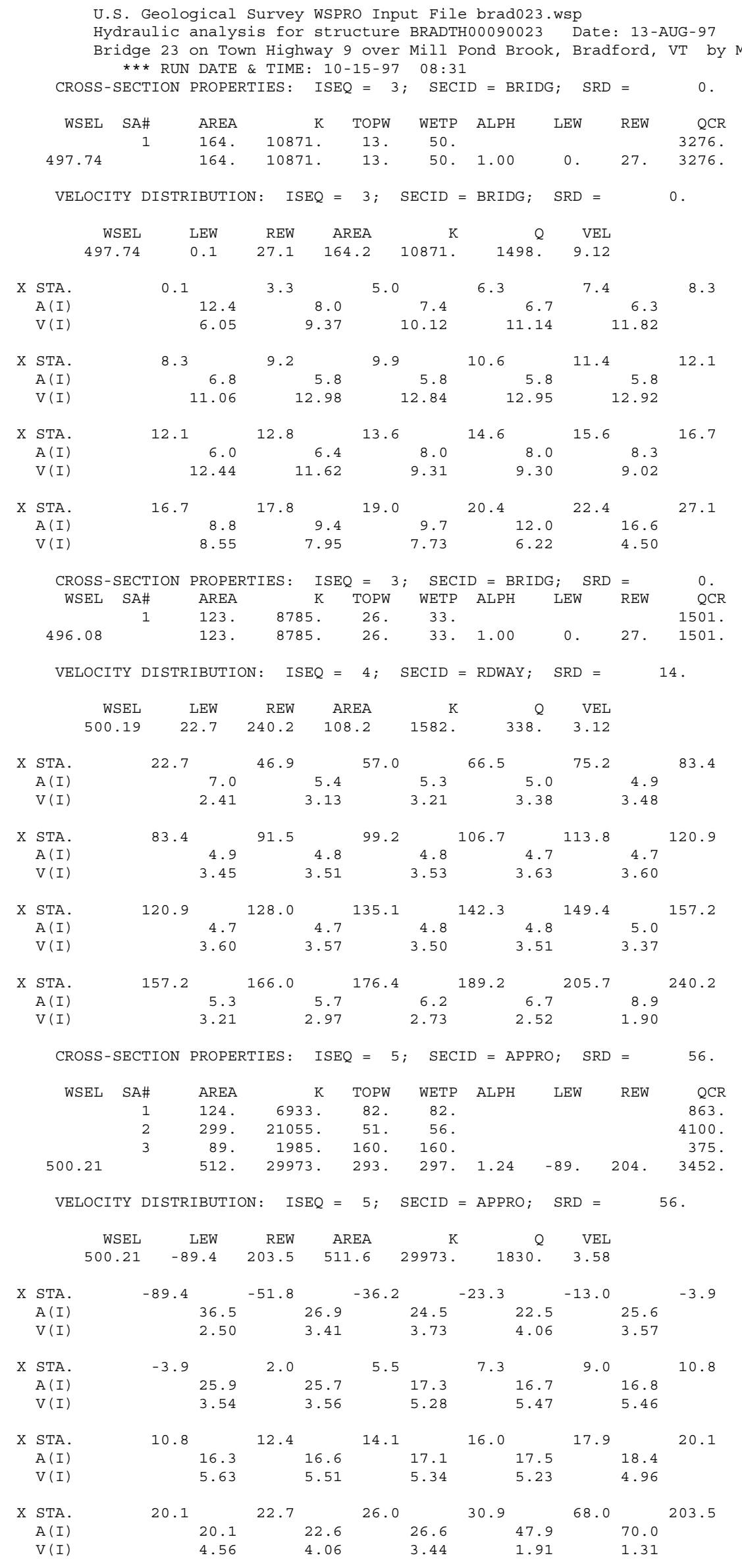


WSPRO OUTPUT FILE (continued)

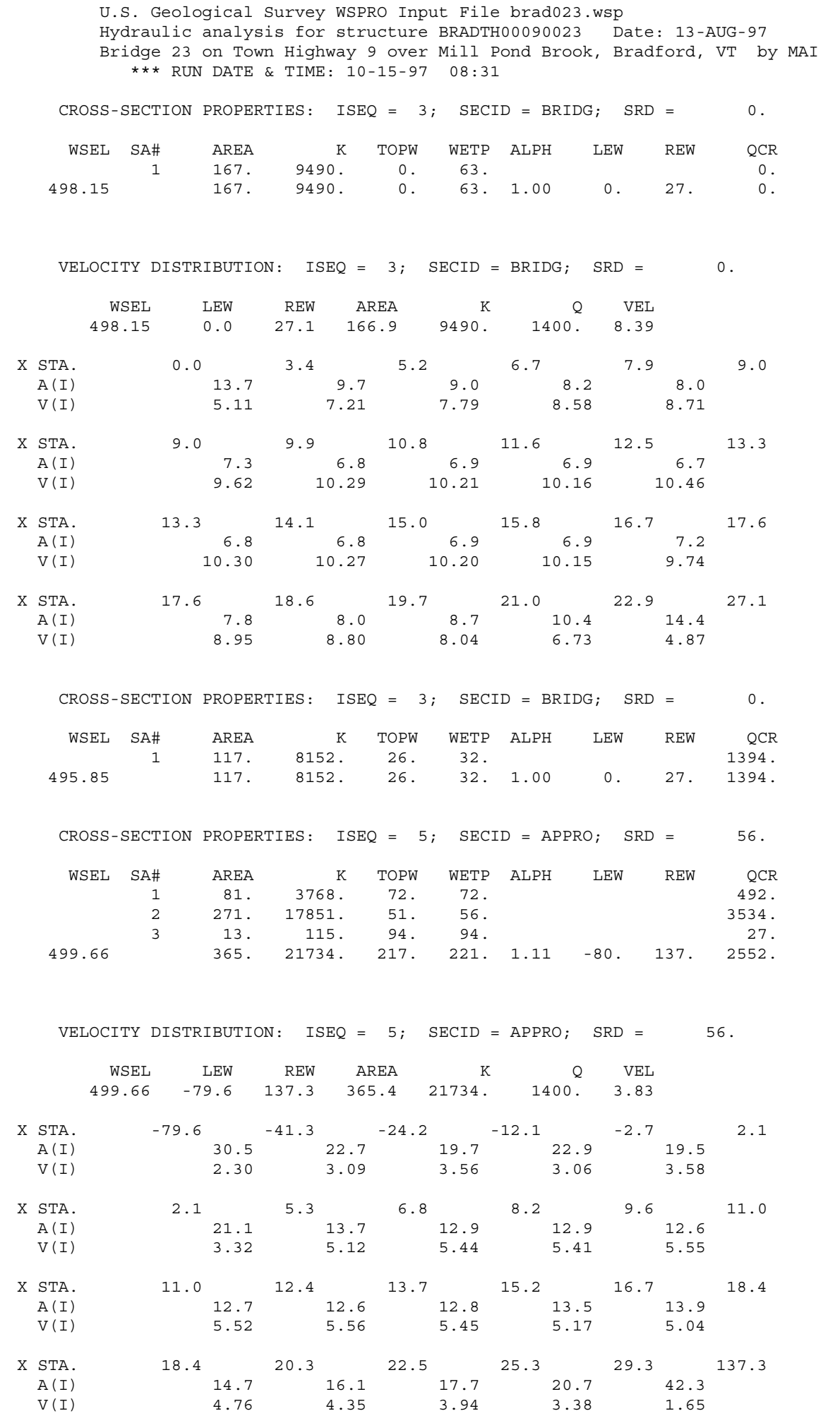


WSPRO OUTPUT FILE (continued)

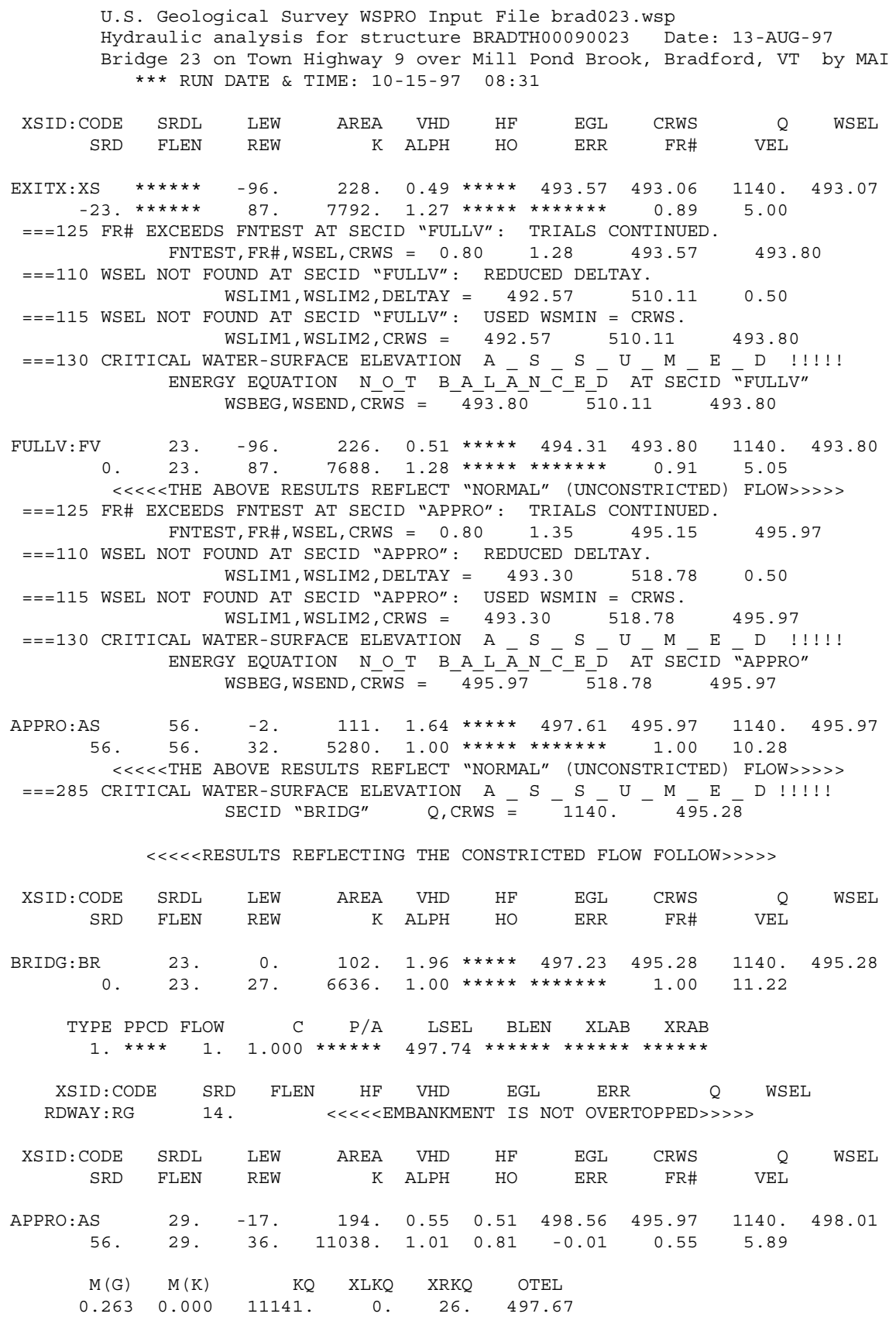

FIRST USER DEFINED TABLE.

\begin{tabular}{|c|c|c|c|c|c|c|c|c|}
\hline XSID : CODE & SRD & LEW & REW & $\mathrm{Q}$ & $\mathrm{K}$ & AREA & VEL & WSEL \\
\hline EXITX:XS & -23 & -96 & 87. & 1140. & 7792 . & 228. & 5.00 & 493.07 \\
\hline FULLV : FV & 0 & -96 & 87. & 1140. & 7688. & 226. & 5.05 & 493.80 \\
\hline BRIDG : BR & 0 & 0 & 27. & 1140. & 6636. & 102. & 11.22 & 495.28 \\
\hline RDWAY : RG & \multicolumn{3}{|c|}{$14 . * * \star * \star * * * * * * * * * *$} & \multicolumn{3}{|c|}{$0 . * * * * * * * * * * * * * * * * * * *$} & \multicolumn{2}{|c|}{$1.00 * * * * * * * *$} \\
\hline APPRO : AS & 56. & -17 & 36. & 1140. & 11038. & 194. & 5.89 & 498.01 \\
\hline XSID : CODE & XLKQ & XRKQ & & & & & & \\
\hline APPRO : AS & 0 & 26 & 1114 & & & & & \\
\hline
\end{tabular}

SECOND USER DEFINED TABLE.

\begin{tabular}{|c|c|c|c|c|c|c|c|c|c|}
\hline XSID : CODE & CRWS & FR\# & YMIN & YMAX & $\mathrm{HF}$ & $\mathrm{HO}$ & VHD & EGL & WSEL \\
\hline EXITX:XS & 493.06 & 0.89 & 487.88 & 509.36 * & $\star \star \star \star \star * \star * \star$ & $\star \star \star \star * *$ & 0.49 & 493.57 & 493.07 \\
\hline FULLV : FV & 493.80 & 0.91 & 488.63 & 510.11 * & 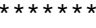 & 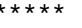 & 0.51 & 494.31 & 493.80 \\
\hline BRIDG : BR & 495.28 & 1.00 & 489.52 & 498.15 * & 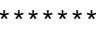 & $\star \star \star \star \star *$ & 1.96 & 497.23 & 495.28 \\
\hline RDWAY : RG & 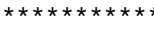 & $\star \star \star \star \star *$ & 499.51 & 519.02 * & 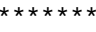 & $\star \star \star \star \star \star *$ & $\star \star \star \star \star \star *$ & 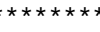 & 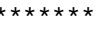 \\
\hline APPRO: AS & 495.97 & 0.55 & 490.27 & 518.78 & 0.51 & 0.81 & 0.55 & 498.56 & 498.01 \\
\hline
\end{tabular}


WSPRO OUTPUT FILE (continued)

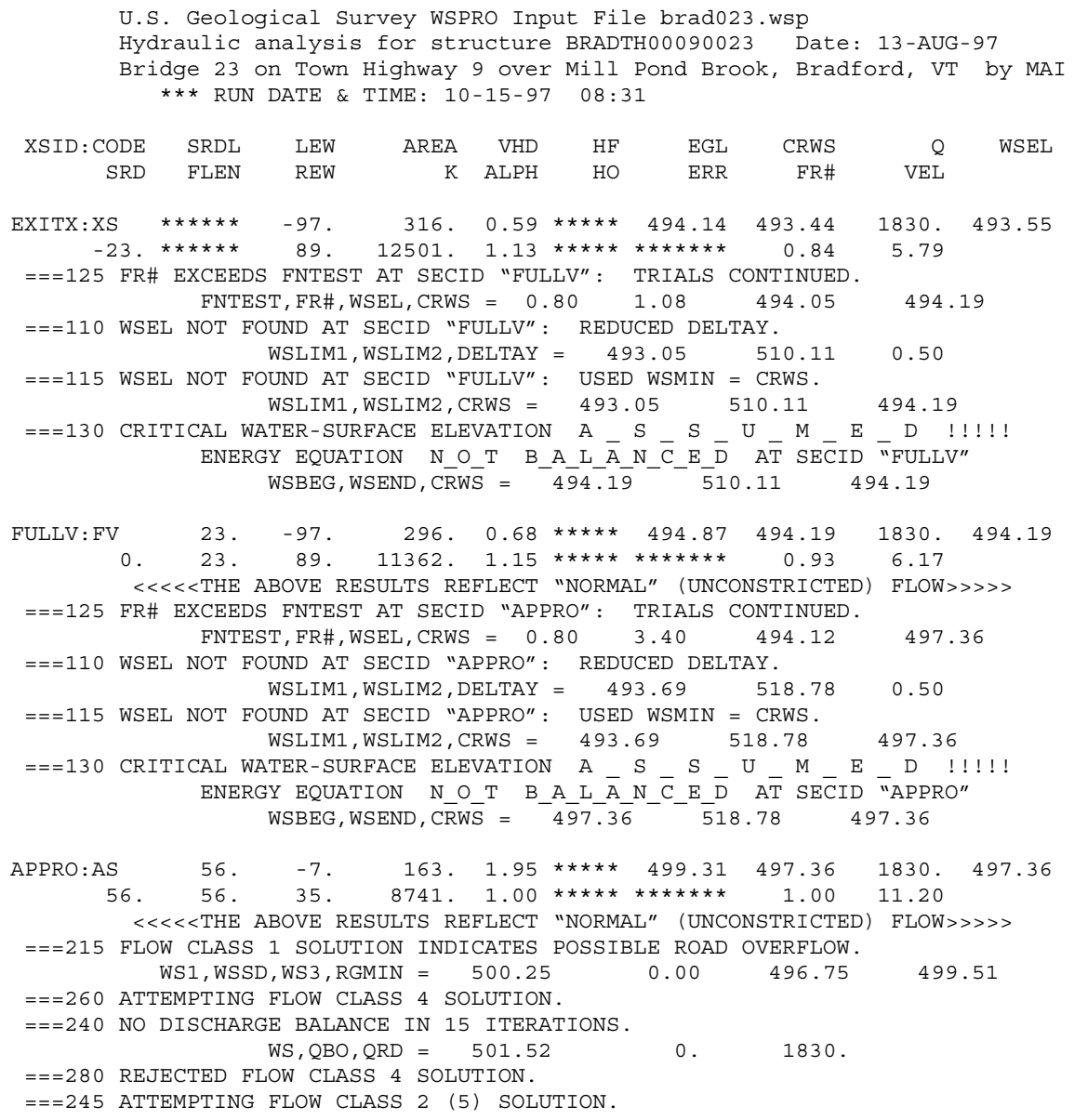


WSPRO OUTPUT FILE (continued)

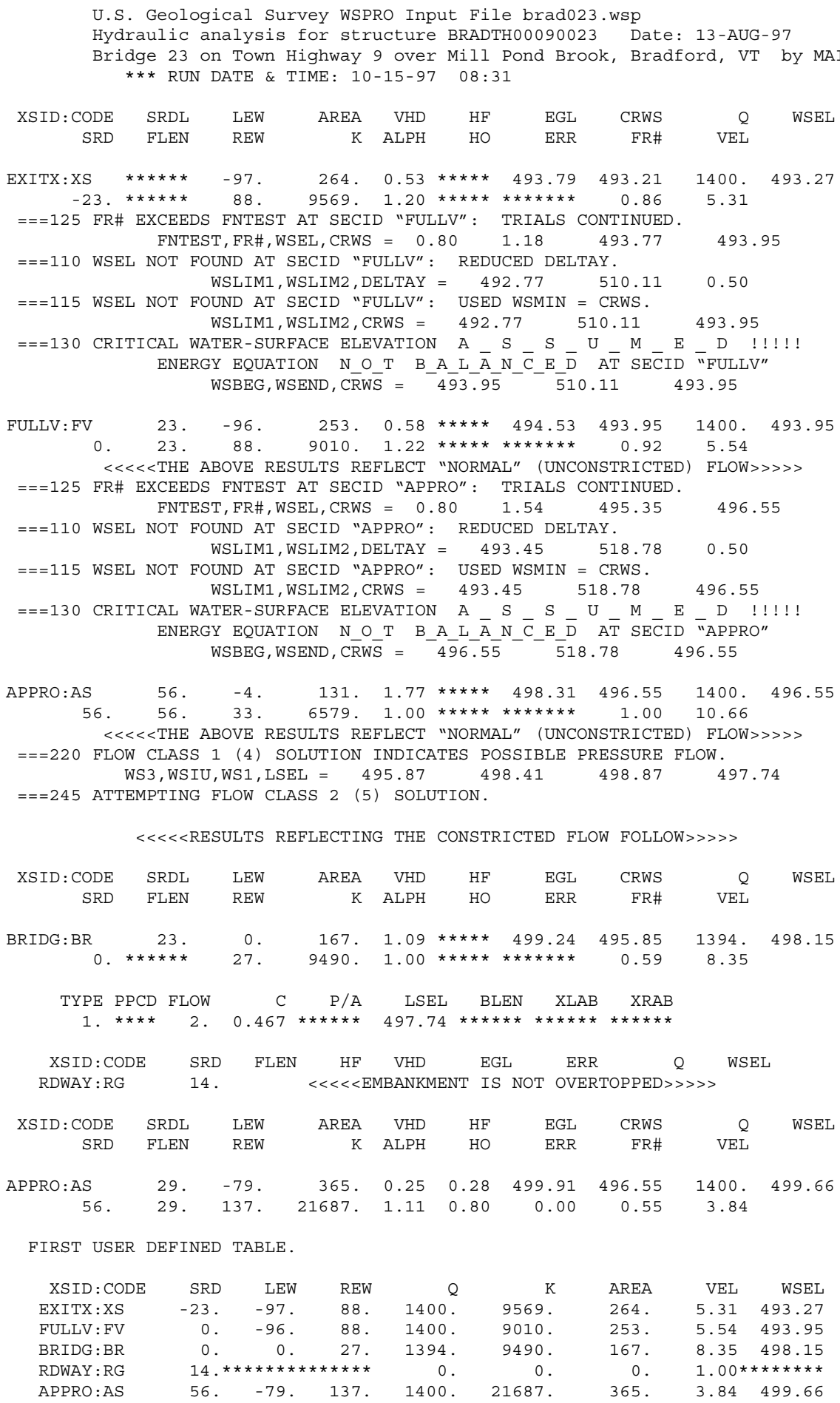

SECOND USER DEFINED TABLE.

$\begin{array}{lcrrrrrrrr}\text { XSID : CODE } & \text { CRWS } & \text { FR\# } & \text { YMIN } & \text { YMAX } & \text { HF } & \text { HO } & \text { VHD } & \text { EGL } & \text { WSEL } \\ \text { EXITX:XS } & 493.21 & 0.86 & 487.88 & 509.36 * * * * * * * * * * & 0.53 & 493.79 & 493.27 \\ \text { FULLV:FV } & 493.95 & 0.92 & 488.63 & 510.11 * * * * * * * * * * * * & 0.58 & 494.53 & 493.95 \\ \text { BRIDG: BR } & 495.85 & 0.59 & 489.52 & 498.15 * * * * * * * * * * & 1.09 & 499.24 & 498.15 \\ \text { RDWAY: RG } & * * * * * * * * * * * * * * * & 499.51 & 519.02 * * * * * * * * * * * & 0.25 & 499.77 * * * * * * * \\ \text { APPRO:AS } & 496.55 & 0.55 & 490.27 & 518.78 & 0.28 & 0.80 & 0.25 & 499.91 & 499.66\end{array}$




\section{APPENDIX C:}

\section{BED-MATERIAL PARTICLE-SIZE DISTRIBUTION}




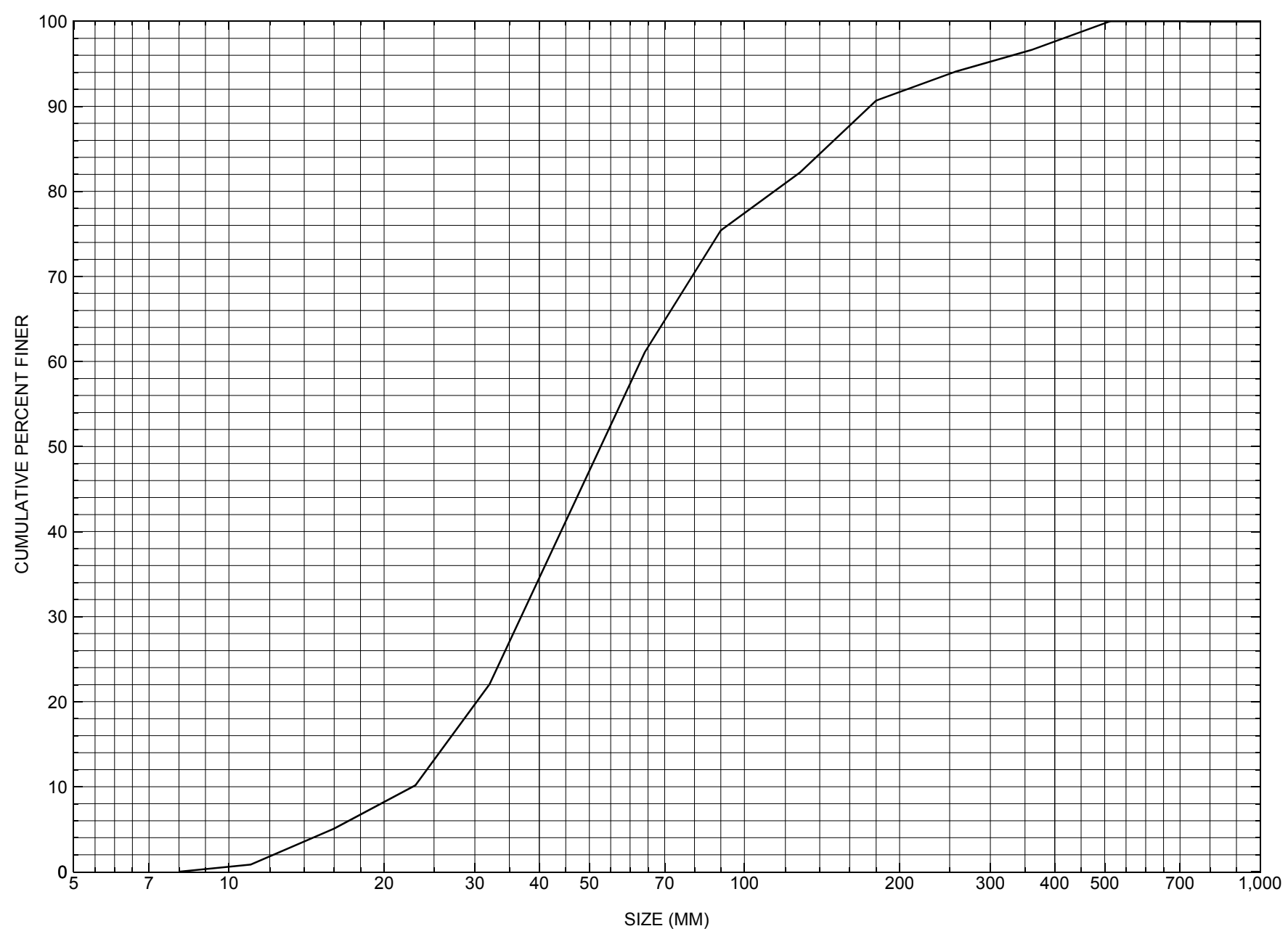

Appendix C. Bed material particle-size distribution for a pebble count in the channel approach of structure BRADTH00090023, in Bradford, Vermont. 


\section{APPENDIX D: \\ HISTORICAL DATA FORM}




\section{Structure Number BRADTH00090023}

\section{General Location Descriptive}

Data collected by (First Initial, Full last name) $\underline{\mathbf{E}}$. Boehmler

Date $(M M / D D / Y Y) \_\mathbf{0 3} / \underline{23} / \underline{95}$

Highway District Number (I - 2; nn) $\mathbf{0 7}$

Town (FIPS place code; I - 4; nnnnn) $\mathbf{0 7 3 7 5}$

Waterway (I - 6) Mill Pond Brook

Route Number TH009

Topographic Map Fairlee

Latitude (I - 16; nnnn.n) $\mathbf{4 3 5 9 2}$
County (FIPS county code; I - 3; nnn)

Mile marker (I - 11; nnn.nnn) $\mathbf{0 0 0 0 0 0}$

Road Name (I - 7): -

Vicinity (I - 9) 0.05 MI JCT TH $9+$ TH 2

Hydrologic Unit Code: $\mathbf{0 1 0 8 0 1 0 3}$

Longitude (i - 17; nnnnn.n) $\mathbf{7 2 0 8 6}$

\section{Select Federal Inventory Codes}

FHWA Structure Number $(I$ - 8) 10090100230901

Maintenance responsibility $(I-21 ; n n) \quad \mathbf{0 3}$

Year built (I - 27; YYYY) 1934

Average daily traffic, ADT (I - 29; nnnnnn) 000400

Year of ADT (I - 30; YY) $\mathbf{9 3}$

Opening skew to Roadway $(I-34 ; n n) \quad \mathbf{0 0}$

Operational status $(I-41 ; X)$ A

Structure type (I - 43; nnn) 104

Approach span structure type $(I-44 ; n n n) \quad \mathbf{0 0 0}$

Number of spans (I - 45; nnn) $\mathbf{0 0 1}$

Number of approach spans (I - 46; nnnn) $\mathbf{0 0 0 0}$

Comments:

The structural inspection report of $6 / 29 / 93$ indicates the structure is a concrete T-beam type bridge. The abutment walls are noted as partially grouted and stone chinked "laid-up" stone blocks with concrete caps. Some of the grouting and stone chinking is reported missing overall. The concrete caps have some minor cracks and spalls reported. There are no wingwalls. The footings are reported as not seen with no undermining or settling indicated as well. Some scour is reported as possible along the right abutment as a log, which may have been used to form the streamward extent of the stone blocks at the base of the wall, is reported visible at the surface along the bottom of the abutment. (Continued, page 33) 


\section{Bridge Hydrologic Data}

Is there hydrologic data available? $\underline{\mathbf{N}}$ if No, type ctrl-n $h \quad$ VTAOT Drainage area $\left(m i^{2}\right)$ : -

Terrain character:

Stream character \& type: -

Streambed material: Gravel and stone

Discharge Data (cfs): $\quad \mathrm{Q}_{2.33}$

$$
\mathrm{Q}_{50}
$$

Record flood date (MM / DD / YY):

Estimated Discharge (cfs):

l

Ice conditions (Heavy, Moderate, Light) : -

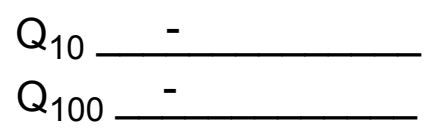

$\mathrm{Q}_{25}$

Water surface elevation $(f t):-$

Velocity at $\mathrm{Q}$ $(\mathrm{ft} / \mathrm{s}):$

The stage increases to maximum highwater elevation (Rapidly, Not rapidly): -

The stream response is (Flashy, Not flashy):

Describe any significant site conditions upstream or downstream that may influence the stream's stage: -

Watershed storage area (in percent):

The watershed storage area is: - (1-mainly at the headwaters; 2- uniformly distributed; 3-immediatly upstream oi the site)

Water Surface Elevation Estimates for Existing Structure:

\begin{tabular}{|l|l|l|l|l|l|}
\hline Peak discharge frequency & $Q_{2.33}$ & $Q_{10}$ & $Q_{25}$ & $Q_{50}$ & $Q_{100}$ \\
Water surface elevation (ft)) & - & - & - & - & - \\
Velocity (ft/sec) & - & - & - & - & - \\
\hline
\end{tabular}

Long term stream bed changes: -

Is the roadway overtopped below the $\mathrm{Q}_{100}$ ? (Yes, No, Unknown): $\mathbf{U} \quad$ Frequency: Relief Elevation $(f t)$ : Discharge over roadway at $Q_{100}\left(f^{3} / \mathrm{sec}\right)$ :

Are there other structures nearby? (Yes, No, Unknown): Upstream distance (miles): Town: If No or Unknown, type ctrl-n os Highway No. : Structure No. : Year Built:

Clear span (ft): Clear Height (ft): Full Waterway $\left(f t^{2}\right)$ : 
Downstream distance (miles): Town: Year Built:

Highway No. : Structure No. : Structure Type:

Clear span $(f t):$ Clear Height $(f t)$ : Full Waterway $\left(f^{2}\right)$ :

Comments:

The log is noted as deteriorated with rotten sections. There is stone and boulder fill protection noted along the front of each abutment wall and around the ends. Further there is some of the same stone fill noted on the banks US and DS of the bridge. The stone fill is noted as washed away from the upstream half of the right abutment.

\section{USGS Watershed Data}

Watershed Hydrographic Data

Drainage area $(D A)$

6.06 $\mathrm{mi}^{2}$

Lake/pond/swamp area

0.03 $\mathrm{mi}^{2}$

Watershed storage (ST) $\%$

Bridge site elevation 510 $\mathrm{ft}$

Headwater elevation 1670 $\mathrm{ft}$

Main channel length 5.19 $\mathrm{mi}$

$10 \%$ channel length elevation $\quad \mathbf{6 0 0}$ $\mathrm{ft} \quad 85 \%$ channel length elevation 1260 $\mathrm{ft}$

Main channel slope $(S)$

(S) $\mathrm{ft} / \mathrm{mi}$

Watershed Precipitation Data

Average site precipitation in Average headwater precipitation in

Maximum 2yr-24hr precipitation event $(124,2)$ in

Average seasonal snowfall (Sn) $\mathrm{ft}$ 


\section{Bridge Plan Data}

Are plans available? $\mathbf{N} \quad$ If no, type ctrl-n $p l \quad$ Date issued for construction $(M M / Y Y Y Y):-$

Project Number

Minimum channel bed elevation:

Low superstructure elevation: USLAB DSLAB USRAB DSRAB Benchmark location description:

NO BENCHMARK INFORMATION

Reference Point (MSL, Arbitrary, Other): Datum (NAD27, NAD83, Other):

Foundation Type: 4

If 1: Footing Thickness

If 2: Pile Type:

If 3: Footing bottom elevation:

Is boring information available? $\mathbf{N}$

Foundation Material Type: 3

(1-Spreadfooting; 2-Pile; 3- Gravity; 4-Unknown)

Footing bottom elevation: -

Briefly describe material at foundation bottom elevation or around piles:

NO FOUNDATION MATERIAL INFORMATION

Comments:

NO PLANS. 


\section{Cross-sectional Data}

Is cross-sectional data available? $\underline{\mathbf{Y}}$

If no, type ctrl-n xs

Source (FEMA, VTAOT, Other)? VTAOT

This cross section is of the upstream face. The low chord elevation is from the survey log done

Comments: for this report on $09 / 07 / 95$. The low chord to bed length data are from the sketch attached to a bridge inspection report dated $06 / 29 / 93$.

\begin{tabular}{|c|c|c|c|c|c|c|c|c|c|c|c|}
\hline Station & $\mathbf{0}$ & 10 & 16 & 20 & 27 & - & - & - & - & - & - \\
\hline Feature & LAB & - & - & - & RAB & - & - & - & - & - & - \\
\hline $\begin{array}{l}\text { Low chord } \\
\text { elevation }\end{array}$ & 498.2 & 497.9 & 497.7 & 497.6 & 497.3 & - & - & - & - & - & - \\
\hline $\begin{array}{l}\text { Bed } \\
\text { elevation }\end{array}$ & 493.1 & 490.0 & 489.5 & 490.1 & 491.7 & - & - & - & - & - & - \\
\hline $\begin{array}{l}\text { Low chord } \\
\text { to bed }\end{array}$ & 5.1 & 7.9 & 8.2 & 7.5 & 5.6 & - & - & - & - & - & - \\
\hline Station & - & - & - & - & - & - & - & - & - & - & - \\
\hline Feature & - & - & - & - & - & - & - & - & - & - & - \\
\hline $\begin{array}{l}\text { Low chord } \\
\text { elevation }\end{array}$ & - & - & - & - & - & - & - & - & - & - & - \\
\hline $\begin{array}{l}\text { Bed } \\
\text { elevation }\end{array}$ & - & - & - & - & - & - & - & - & - & - & - \\
\hline $\begin{array}{l}\text { Low chord } \\
\text { to bed }\end{array}$ & - & - & - & - & - & - & - & - & - & - & - \\
\hline
\end{tabular}

Source (FEMA, VTAOT, Other)?

Comments: -

\begin{tabular}{|c|c|c|c|c|c|c|c|c|c|c|c|}
\hline Station & - & - & - & - & - & - & - & - & - & - & - \\
\hline Feature & - & - & - & - & - & - & - & - & - & - & - \\
\hline $\begin{array}{l}\text { Low chord } \\
\text { elevation }\end{array}$ & - & - & - & - & - & - & - & - & - & - & - \\
\hline $\begin{array}{l}\text { Bed } \\
\text { elevation }\end{array}$ & - & - & - & - & - & - & - & - & - & - & - \\
\hline $\begin{array}{l}\text { Low chord } \\
\text { to bed }\end{array}$ & - & - & - & - & - & - & - & - & - & - & - \\
\hline Station & - & - & - & - & - & - & - & - & - & - & - \\
\hline Feature & - & - & - & - & - & - & - & - & - & - & - \\
\hline $\begin{array}{l}\text { Low chord } \\
\text { elevation }\end{array}$ & - & - & - & - & - & - & - & - & - & - & - \\
\hline $\begin{array}{l}\text { Bed } \\
\text { elevation }\end{array}$ & - & - & - & - & - & - & - & - & - & - & - \\
\hline $\begin{array}{l}\text { Low chord } \\
\text { to bed }\end{array}$ & - & - & - & - & - & - & - & - & - & - & - \\
\hline
\end{tabular}




\section{APPENDIX E: \\ LEVEL I DATA FORM}


U. S. Geological Survey

Bridge Field Data Collection and Processing Form

Qa/Qc Check by: CG Date: $02 / 23 / 96$

\section{Structure Number BRADTH00090023}

\section{A. General Location Descriptive}

1. Data collected by (First Initial, Full last name) $\mathbf{T}$. Severance

Date $(M M / D D / Y Y)$

09

$07 / 1995$

2. Highway District Number $\mathbf{0 7}$

County Orange (017)

Waterway (I - 6) Mill Pond Brook

Route Number TH 009

3. Descriptive comments:

The site is located $\mathbf{0 . 0 5}$ miles to the junction with Town Highway 2.
Mile marker $\mathbf{0}$

Town Bradford (07375)

Road Name -

Hydrologic Unit Code: $\mathbf{0 1 0 8 0 1 0 3}$

\section{B. Bridge Deck Observations}
RBUS 2
LBDS 2
RBDS 6
Overall 2

(2b us, ds,lb,rb: 1- Urban; 2- Suburban; 3- Row crops; 4- Pasture; 5- Shrub- and brushland; 6- Forest; 7- Wetland)
5. Ambient water surface... US 2
UB 1 DS 2
(1- pool; 2- riffle)

6. Bridge structure type 1 (1- single span; 2-multiple span; 3- single arch; 4- multiple arch; 5-cylindrical culvert; 6- box culvert; or 7- other)
7. Bridge length $\mathbf{3 3 . 0}$
(feet)
Span length $\mathbf{2 9 . 0}$
(feet)
Bridge width 23.3 (feet)

\section{Road approach to bridge:}
8. LB 2 RB 1
( 0 even, 1- lower, 2- higher)
9. LB 1
RB 1
(1- Paved, 2- Not paved)

10. Embankment slope (run / rise in feet / foot)

US left

US right

\begin{tabular}{|c|c|c|c|}
\hline \multicolumn{2}{|c|}{ Protection } & \multirow{2}{*}{ 13.Erosion } & 14.Severity \\
\hline 11.Type & 12.Cond. & $\mathbf{3}$ & $\mathbf{1}$ \\
\hline $\mathbf{0}$ & - & - & $\mathbf{1}$ \\
$\mathbf{0}$ & - & - & - \\
$\mathbf{0}$ & - & $\mathbf{0}$ & - \\
\hline $\mathbf{0}$ & - & $\mathbf{0}$ & - \\
\hline
\end{tabular}

Bank protection types: 0- none; 1- < 12 inches,

2- $<36$ inches; $3-<48$ inches;

4- < 60 inches; 5- wall / artificial levee

Bank protection conditions: 1- good; 2- slumped;

3- eroded; 4- failed

Erosion: 0 - none; 1- channel erosion; 2 -

road wash; 3- both; 4- other

Erosion Severity: 0 - none; 1- slight; 2- moderate; 3- severe

\section{Channel approach to bridge (BF):}

15. Angle of approach: $\mathbf{5 0}$

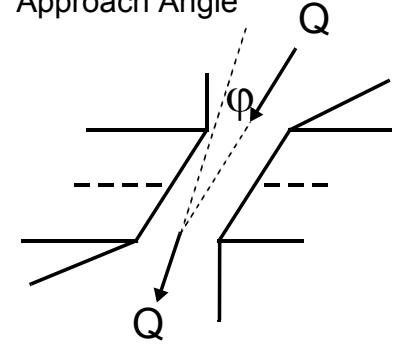

17. Channel impact zone 1:

Where? RB (LB, RB)

Range? 0 feet DS

Channel impact zone 2:

Where? RB $(L B, R B)$

Range? $\underline{\mathbf{0}}$ feet $\underline{\mathbf{D S}}$

Impact Severity: 0- none to very slight; 1- Slight; 2- Moderate; 3- Severe
16. Bridge skew: 20 Bridge Skew Angle

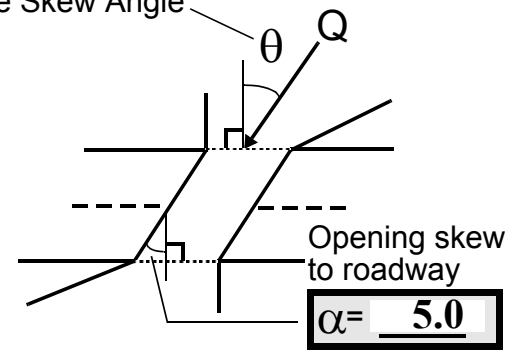

\section{Exist? $\mathbf{Y}(Y$ or $N)$}

Severity 1

(US, UB, DS) to $\underline{45 \quad \text { feet } \underline{\mathbf{U S}}}$

Exist? $\mathbf{Y}(Y$ or $N)$

Severity $\underline{\mathbf{0}}$

$U B, D S)$ to $\underline{\mathbf{5 0}}$ feet $\underline{\mathbf{D S}}$ 
18. Bridge Type: $\mathbf{1 b}$

1a- Vertical abutments with wingwalls

$1 \mathrm{~b}$ - Vertical abutments without wingwalls

2- Vertical abutments and wingwalls, sloping embankment Wingwalls parallel to abut. face

3- Spill through abutments

4- Sloping embankment, vertical wingwalls and abutments Wingwall angle less than $90^{\circ}$.

19. Bridge Deck Comments (surface cover variations, measured bridge and span lengths, bridge type variations, approach overflow width, etc.)

4. There is a "laid-up" stone retaining wall on the left bank DS. The DS right bank is forested, but all other immediate overbanks have dwellings and roads.

7. The bridge dimension values are from the VTAOT database. The measured bridge length is $33 \mathrm{ft}$, span length is $30 \mathrm{ft}$, and bridge width is $23.2 \mathrm{ft}$.

\section{Upstream Channel Assessment}

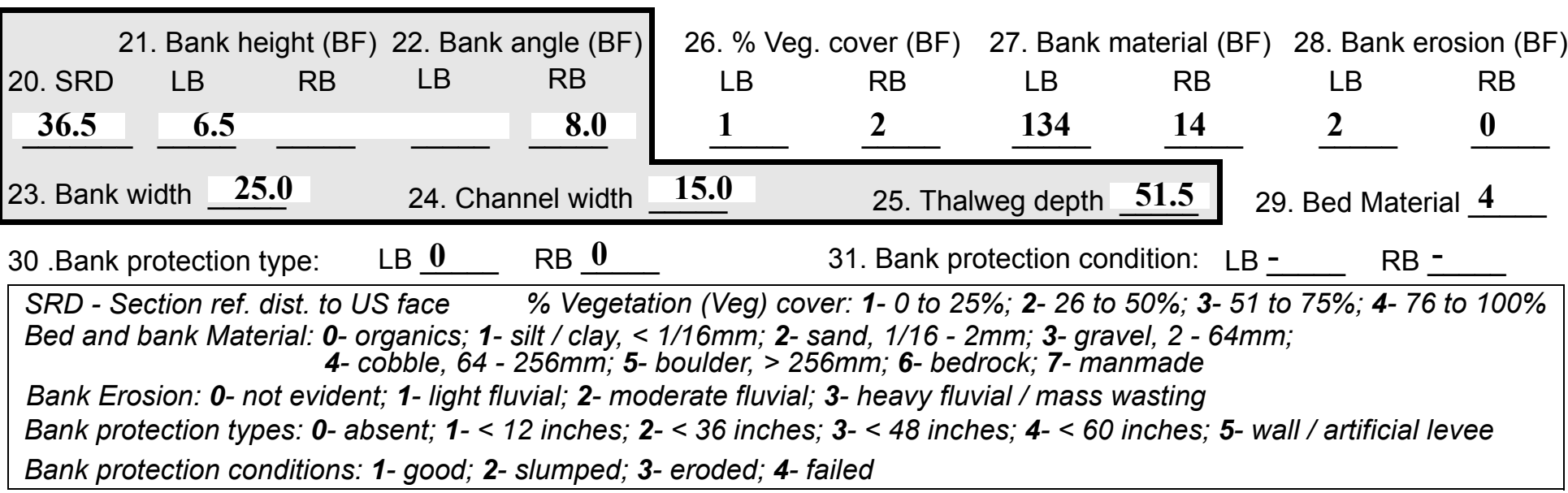

32. Comments (bank material variation, minor inflows, protection extent, etc.): 

feet US (US, UB) to $\mathbf{2 0}$ feet $\underline{\mathbf{U S}}$ (US, UB, DS) positioned 65 \%LB to 100 \%RB

37. Material: $\mathbf{3 1 4}$

38. Point or side bar comments (Circle Point or Side; Note additional bars, material variation, status, etc.):

The point bar material is primarily gravel and silt/sand, but there is some cobble.

39. Is a cut-bank present? $\mathbf{Y}$ (Y or if $N$ type $c t r-n c b)$

41. Mid-bank distance: $\mathbf{4 0}$

43. Bank damage: 1

42. Cut bank extent: 65

40. Where? $\underline{\mathbf{L B}}$ (LB or RB) feet $\underline{\mathbf{U S}}$ (US, UB) to $\underline{\mathbf{3 3}}$ feet $\underline{\mathbf{U S}}$ (US, UB, DS) (1- eroded and/or creep; 2- slip failure; 3- block failure)

44. Cut bank comments (eg. additional cut banks, protection condition, etc.):

Tree roots are exposed. Cobbles are falling out of the base of the bank. The grass is slumped at the top edge of the bank.

\section{Is channel scour present? $\mathbf{Y}$ ( $Y$ or if $N$ type ctrl-n cs)}

47. Scour dimensions: Length 10 Width 5 Depth : 0.5

46. Mid-scour distance: $\underline{4}$

48. Scour comments (eg. additional scour areas, local scouring process, etc.):

There is some localized scour upstream of the bridge (beyond 2 bridge lengths).

49. Are there major confluences? $\mathbf{N}$

51. Confluence 1: Distance Confluence 2: Distance 52. Enters on Enters on 54. Confluence comments (eg. confluence name):

NO MAJOR CONFLUENCES
50. How many? -

53. Type(1- perennial; 2- ephemeral)

Type (1-perennial; 2-ephemeral) ( $L B$ or $R B)$

\section{Under Bridge Channel Assessment}

55. Channel restraint (BF)? LB 2

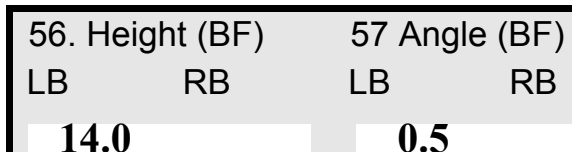

58. Bank width (BF) (1- natural bank; 2- abutment; 3- artificial levee)

Bed and bank Material: 0- organics; 1- silt / clay, < 1/16mm; 2- sand, 1/16 - 2mm; 3- gravel, 2 - 64mm; 4- cobble, 64 - 256mm; 5- boulder, > 256mm; 6- bedrock; 7- manmade

\begin{tabular}{|c|c|c|c|}
\hline \multicolumn{2}{|c|}{ 61. Material (BF) } & \multicolumn{2}{|c|}{ 62. Erosion (BF) } \\
\hline LB & $\mathrm{RB}$ & LB & RB \\
\hline 2 & 7 & 7 & - \\
\hline
\end{tabular}

60. Thalweg depth $\lcm{90.0}$
63. Bed Material -

Bank Erosion: 0- not evident; 1- light fluvial; 2- moderate fluvial; 3- heavy fluvial / mass wasting

64. Comments (bank material variation, minor inflows, protection extent, etc.):

34 
65. Debris and Ice Is there debris accumulation?

67. Debris Potential $\underline{3}$ (1- Low; 2- Moderate; 3- High)

69. Is there evidence of ice build-up? $\underline{2}(Y$ or $N)$

70. Debris and Ice Comments:

1

There is greater than $8 \mathrm{ft}$ of vertical distance between the channel and the deck. The bridge is not particularly constrictive. There is some debris in the channel. Trees are leaning into the channel upstream.
$(Y$ or $N)$ 66. Where? $\mathbf{Y}$

68. Capture Efficiency 2

(1- Upstream; 2- At bridge; 3-Both)

Ice Blockage Potential $\mathbf{N}$

(1-Low; 2- Moderate; 3- High)

(1-Low; 2- Moderate; 3- High)

\begin{tabular}{|l|c|c|c|c|c|c|c|c|}
\hline Abutments & $\begin{array}{c}71 . \text { Attack } \\
\angle \text { (BF) }\end{array}$ & $\begin{array}{c}\text { 72. Slope } \angle \\
\text { (Qmax) }\end{array}$ & $\begin{array}{c}\text { 73. Toe } \\
\text { loc. (BF) }\end{array}$ & $\begin{array}{c}\text { 74. Scour } \\
\text { Condition }\end{array}$ & $\begin{array}{c}75 . \text { Scour } \\
\text { depth }\end{array}$ & $\begin{array}{c}\text { 76. Exposure } \\
\text { depth }\end{array}$ & 77. Material & 78. Length \\
\hline LABUT & & - & $\mathbf{9 0}$ & $\mathbf{2}$ & $\mathbf{0}$ & - & - & $\mathbf{9 0 . 0}$ \\
\hline RABUT & $\mathbf{2}$ & $\mathbf{2 0}$ & $\mathbf{9 0}$ & & & $\mathbf{2}$ & $\mathbf{2}$ & $\mathbf{2 7 . 0}$ \\
\hline
\end{tabular}

Pushed: $L B$ or RB

Toe Location (Loc.): 0- even, 1- set back, 2- protrudes

Scour cond.: 0- not evident; 1- evident (comment); 2- footing exposed; 3-undermined footing; 4- piling exposed; 5- settled; 6- failed

Materials: 1- Concrete; 2- Stone masonry or drywall; 3- steel or metal; 4- wood

79. Abutment comments (eg. undermined penetration, unusual scour processes, debris, etc.):

0

0.5

2

77. The abutments are "laid-up" granite blocks with concrete caps.

$75 \&$ 76. The footing is exposed along the right abutment in places, but there is no water along the right abutment at this time.

The bridge appears to have been widened. There are remains of what appears to be the base of the old left abutment.

There is some localized scour beneath the bridge. One hole is by the upstream bridge face with dimensions of $2 \mathrm{ft}$ long by $2 \mathrm{ft}$ wide by $0.25 \mathrm{ft}$ deep. The other hole is to the left of the bridge center point and has dimensions

80. Wingwalls:

Exist? Material? Scour Scour Exposure $\begin{aligned} & 81 . \\ & \text { Angle? Length? }\end{aligned}$

USLWW: of 3 Condition? depth? depth?

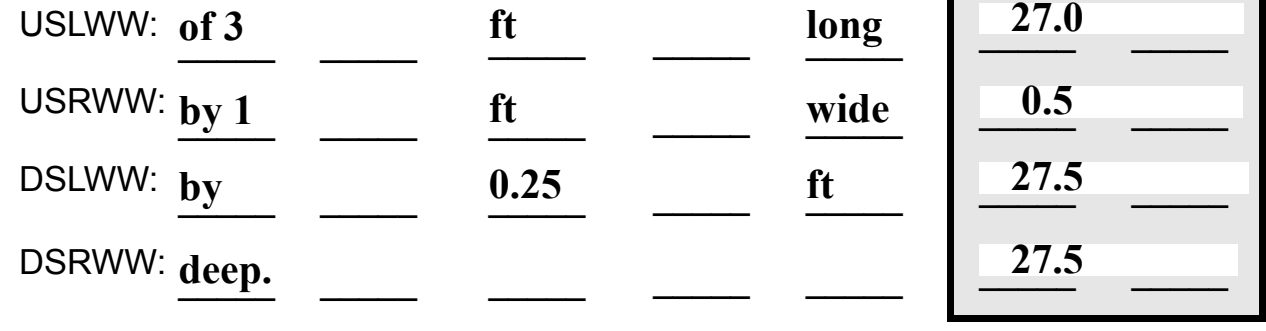

Wingwall materials: 1- Concrete; 2- Stone masonry or drywall; 3- steel or metal; 4- wood

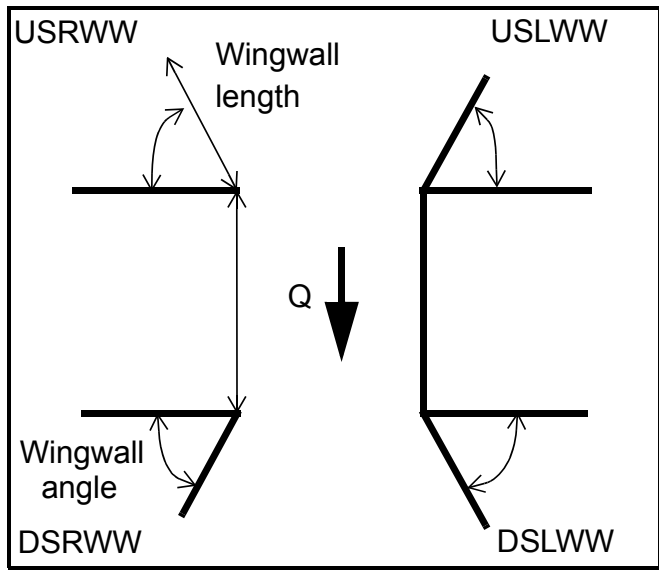

82. Bank / Bridge Protection:

\begin{tabular}{|l|l|l|l|l|l|l|l|c|}
\hline Location & USLWW & USRWW & LABUT & RABUT & LB & RB & DSLWW & DSRWW \\
\hline Type & N & - & - & - & - & N & - & $\mathbf{1}$ \\
\hline Condition & - & - & - & N & - & - & - & $\mathbf{4}$ \\
\hline Extent & - & $\mathbf{N}$ & - & - & - & - & $\mathbf{2}$ & $\mathbf{2}$ \\
\hline
\end{tabular}

Bank / Bridge protection types: 0- absent; 1- < 12 inches; 2- < 36 inches; 3- < 48 inches; 4- < 60 inches; 
83. Wingwall and protection comments (eg. undermined penetration, unusual scour processes, etc.):

1
4
2
1
2
2
2
2
-
-
-

\section{Piers:}

84. Are there piers? _ _ (Y or if $N$ type ctrl-n pr)

\begin{tabular}{|l|l|l|l|l|l|l|l|}
\hline \multirow{2}{*}{$\begin{array}{l}85 . \\
\text { Pier no. }\end{array}$} & \multicolumn{3}{|c|}{ width (w) feet } & \multicolumn{3}{c|}{ elevation (e) feet } \\
\cline { 2 - 8 } & w1 & w2 & w3 & e@w1 & e@w2 & e@w3 \\
\hline Pier 1 & - & - & - & - & - & - \\
\hline Pier 2 & - & - & - & - & - & - \\
\hline Pier 3 & - & - & - & - & - & - \\
\hline Pier 4 & - & - & - & - & - & - \\
\hline
\end{tabular}

\begin{tabular}{|c|c|c|c|c|}
\hline Level 1 Pier Descr. & 1 & 2 & 3 & 4 \\
\hline 86. Location (BF) & - & walls, & abut- & left \\
\hline 87. Type & - & but & ment & abut \\
\hline 88. Material & $\mathbf{0}$ & stone & s. & ment \\
\hline 89. Shape & - & is & (This & , but \\
\hline 90. Inclined? & - & stack & is & $\mathbf{a}$ \\
\hline 91. Attack $\angle(B F)$ & 2 & ed at & not & laid- \\
\hline 92. Pushed & 1 & the & true & up \\
\hline 93. Length (feet) & - & - & - & - \\
\hline 94. \# of piles & 4 & end & at & wall \\
\hline 95. Cross-members & Ther & cor- & the & meet \\
\hline 96. Scour Condition & e are & ners & dow & s the \\
\hline 97. Scour depth & no & of & nstre & left \\
\hline 98. Exposure depth & wing & the & am & abut \\
\hline
\end{tabular}

LFP, LTB, LB, MCL, MCM, MCR, RB, RTB, RFP

1- Solid pier, 2- column, 3- bent

1-Wood; 2- concrete; 3- metal; 4- stone

1- Round; 2- Square; 3- Pointed

Y-yes; N- no

$L B$ or $R B$

0- none; 1- laterals; 2- diagonals; 3- both

0- not evident; 1- evident (comment);

2- footing exposed; 3- piling exposed;

4- undermined footing; 5- settled; 6- failed 
99. Pier comments (eg. undermined penetration, protection and protection extent, unusual scour processes, etc.):

ment at a 90 degree angle.)

Remains of the old left abutment exist. The space between the old and current abutment is filled in with gravel, some boulders and silt. The old abutment base is about $2 \mathrm{ft}$ high.

100.

\section{E. Downstream Channel Assessment}

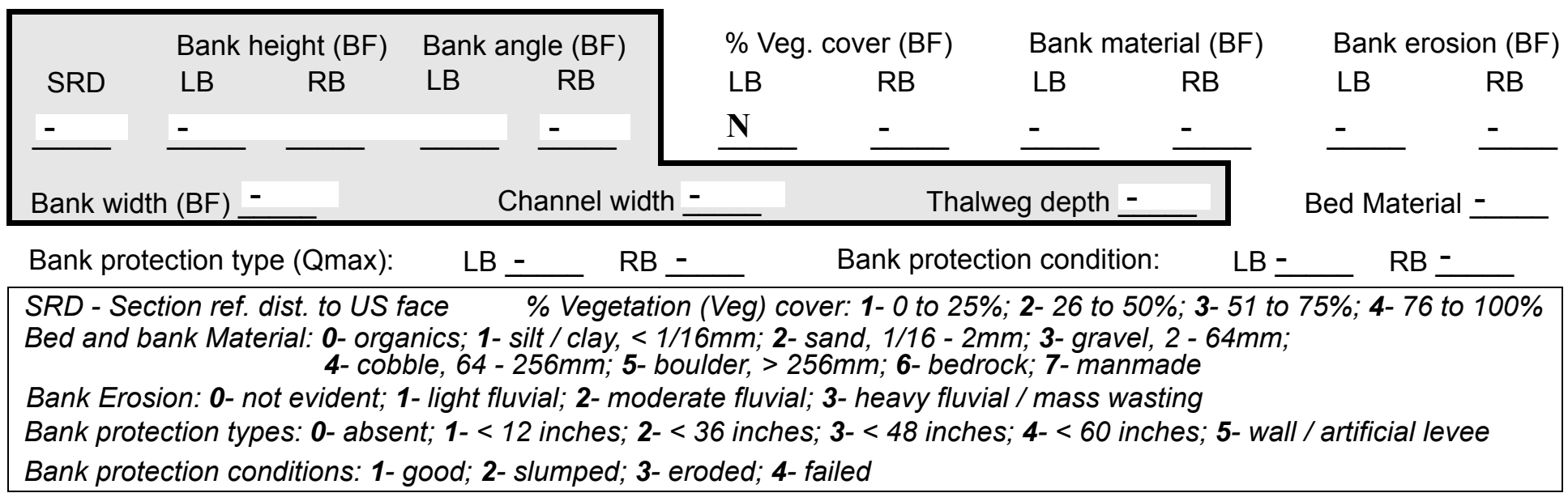

Comments (eg. bank material variation, minor inflows, protection extent, etc.):$$
-
$$$$
-
$$

$-$

$-$

$-$

$-$

$-$

$-$

-

-

$-$

$-$

\section{Is a drop structure present? - ( $Y$ or N, if $N$ type ctrl-n ds) 102. Distance: -}

103. Drop: -_ feet 104. Structure material: ___ (1- steel sheet pile; 2- wood pile; 3- concrete; 4- other)

105. Drop structure comments (eg. downstream scour depth): 
106. Point/Side bar present? (Y or $N$. if $N$ type ctrl-n pb)Mid-bar distance:

Mid-bar width: -

Point bar extent: feet -

(US, UB, DS) to feet (US, UB, DS) positioned $\%$ LB to $\% \mathrm{RB}$ Material:

Point or side bar comments (Circle Point or Side, note additional bars, material variation, status, etc.):

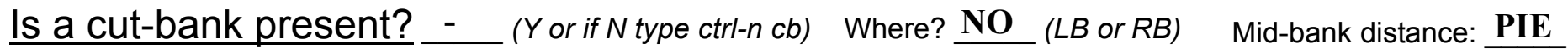
Cut bank extent: $\underline{\mathbf{R S}}$ feet __ (US, UB, DS) to feet ___ (US, UB, DS)

Bank damage: (1- eroded and/or creep; 2- slip failure; 3- block failure)

Cut bank comments (eg. additional cut banks, protection condition, etc.):

Is channel scour present? Scour dimensions: Length $\underline{4}$ Width 14 ( $Y$ or if $N$ type ctrl-n cs)

Mid-scour distance: 1

Scour comments (eg. additional scour areas, local scouring process, etc.): 453

0

0

Are there major confluences? Confluence 1: Distance down

Confluence 2: Distance chan( $Y$ or if $N$ type ctrl-n $m c)$

Positioned 1 $\%$ LB to 1 $\%$ RB Confluence comments (eg. confluence name):

similar to the upstream channel in that cobbles are falling out of the base of the banks, but the banks downstream are not as high as upstream. There are some exposed roots.

\section{F. Geomorphic Channel Assessment}

107. Stage of reach evolution
1- Constructed

2- Stable

3- Aggraded

4- Degraded

5- Laterally unstable

6- Vertically and laterally unstable 
108. Evolution comments (Channel evolution not considering bridge effects; See HEC-20, Figure 1 for geomorphic descriptors):

e stream varies with riffles and pools. 


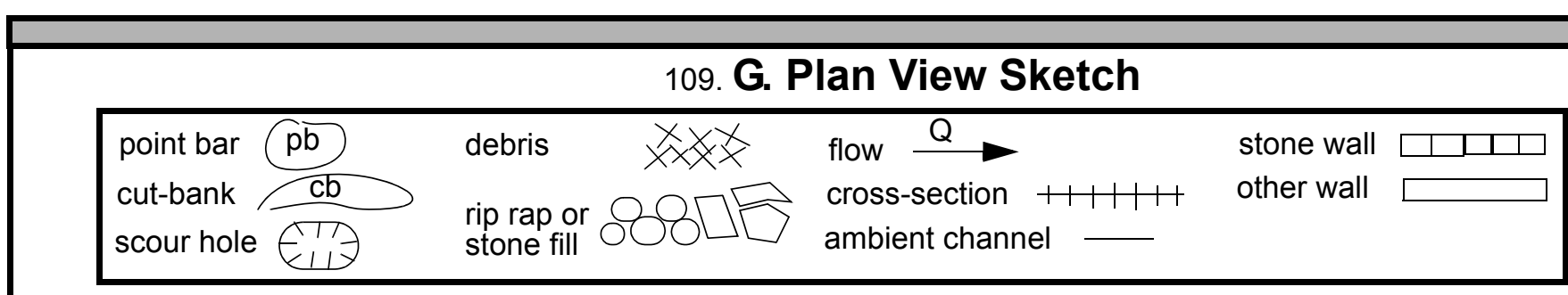


APPENDIX F:

SCOUR COMPUTATIONS 


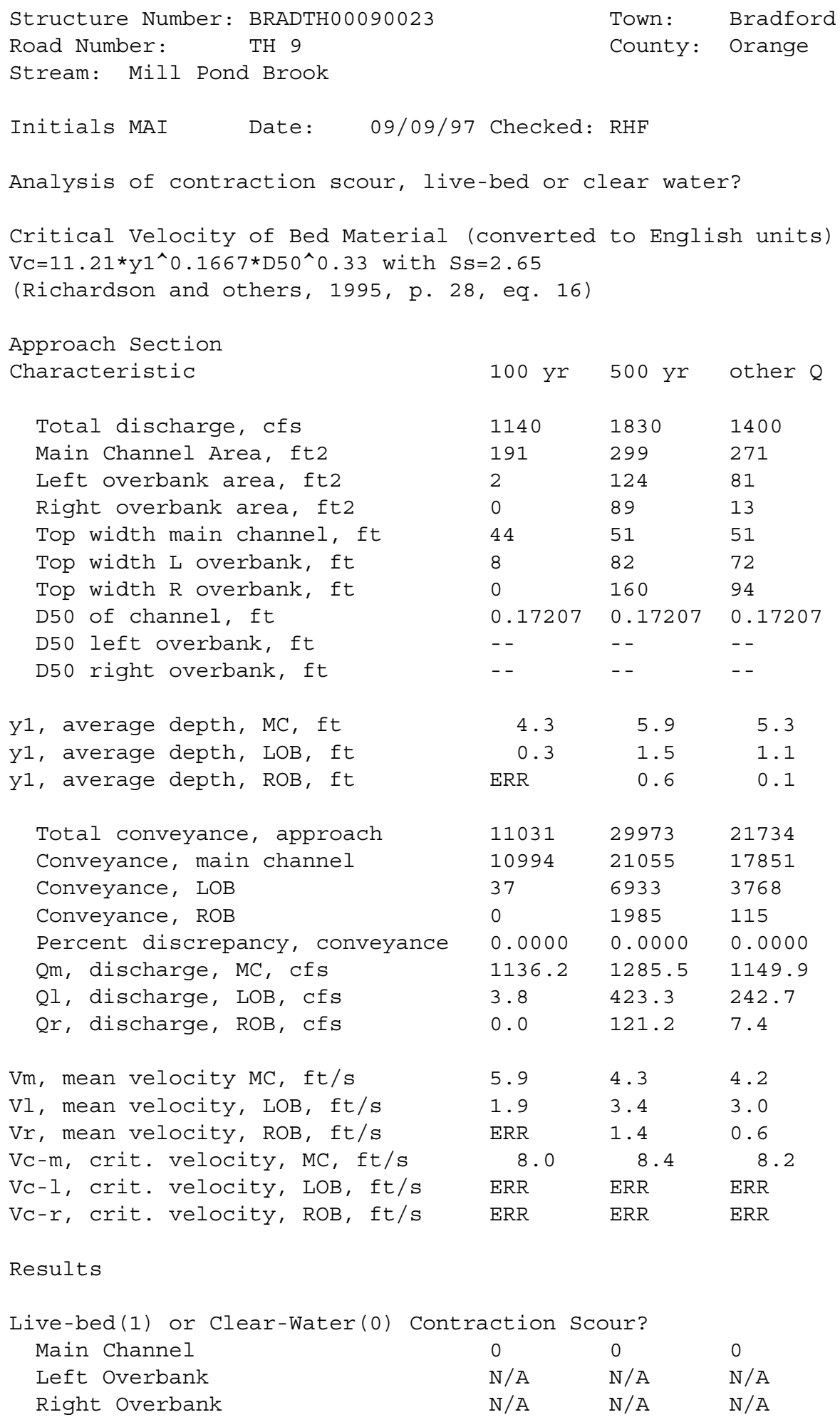


Clear water Contraction Scour in MAIN CHANNEL

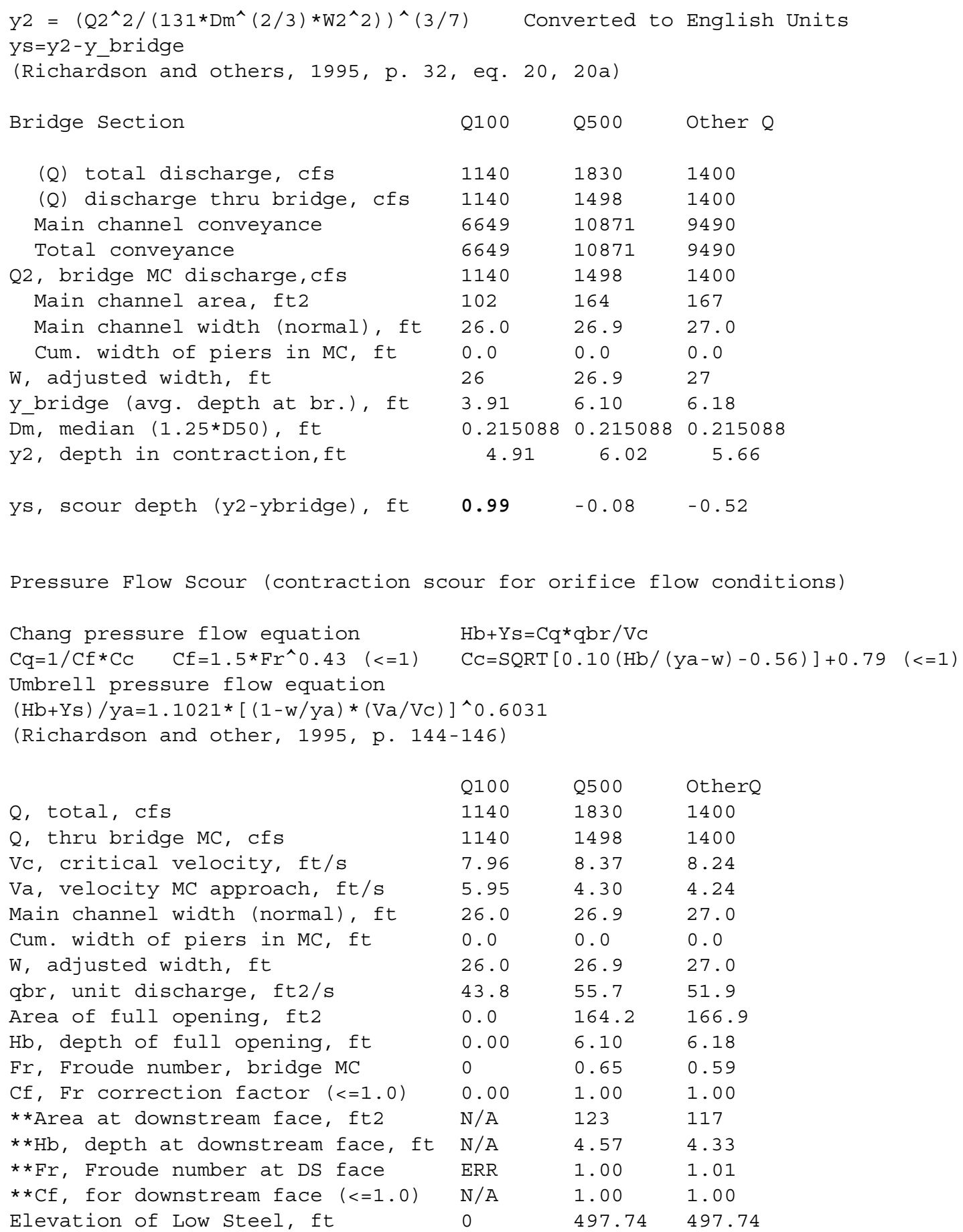




$\begin{array}{llll}\text { Elevation of Bed, ft } & 0.00 & 491.64 & 491.56 \\ \text { Elevation of Approach, ft } & 0 & 500.21 & 499.66 \\ \text { Friction loss, approach, ft } & 0 & 0.25 & 0.28 \\ \text { Elevation of WS immediately US, ft } & 0.00 & 499.96 & 499.38 \\ \text { ya, depth immediately US, ft } & 0.00 & 8.32 & 7.82 \\ \text { Mean elevation of deck, ft } & 0 & 500.42 & 500.42 \\ \text { w, depth of overflow, ft (>=0) } & 0.00 & 0.00 & 0.00 \\ \text { CC, vert contrac correction (<=1.0) } & \text { ERR } & 0.92 & 0.94 \\ \text { *CC, for downstream face (<=1.0) } & \text { ERR } & 0.79 & 0.79 \\ \text { Ys, scour w/Chang equation, ft } & \text { N/A } & 1.11 & 0.50 \\ \text { Ys, scour w/Umbrell equation, ft } & \text { N/A } & 0.03 & -0.40\end{array}$

**=for UNsubmerged orifice flow using estimated downstream bridge face properties.

**Ys, scour w/Chang equation, ft N/A $3.85 \quad 3.64$

**Ys, scour w/Umbrell equation, ft ERR $1.56 \quad 1.44$

In UNsubmerged orifice flow, an adjusted scour depth using the Laursen equation results and the estimated downstream bridge face properties can also be computed (ys=y2-ybridgeDs)

y2, from Laursen's equation, ft $4.91 \quad 6.02 \quad 5.66$

WSEL at downstream face, ft $\quad--\quad 496.08 \quad 495.85$

Depth at downstream face, ft N/A $4.57 \quad 4.33$

Ys, depth of scour (Laursen), ft $\mathrm{N} / \mathrm{A} \quad 1.45 \quad 1.33$

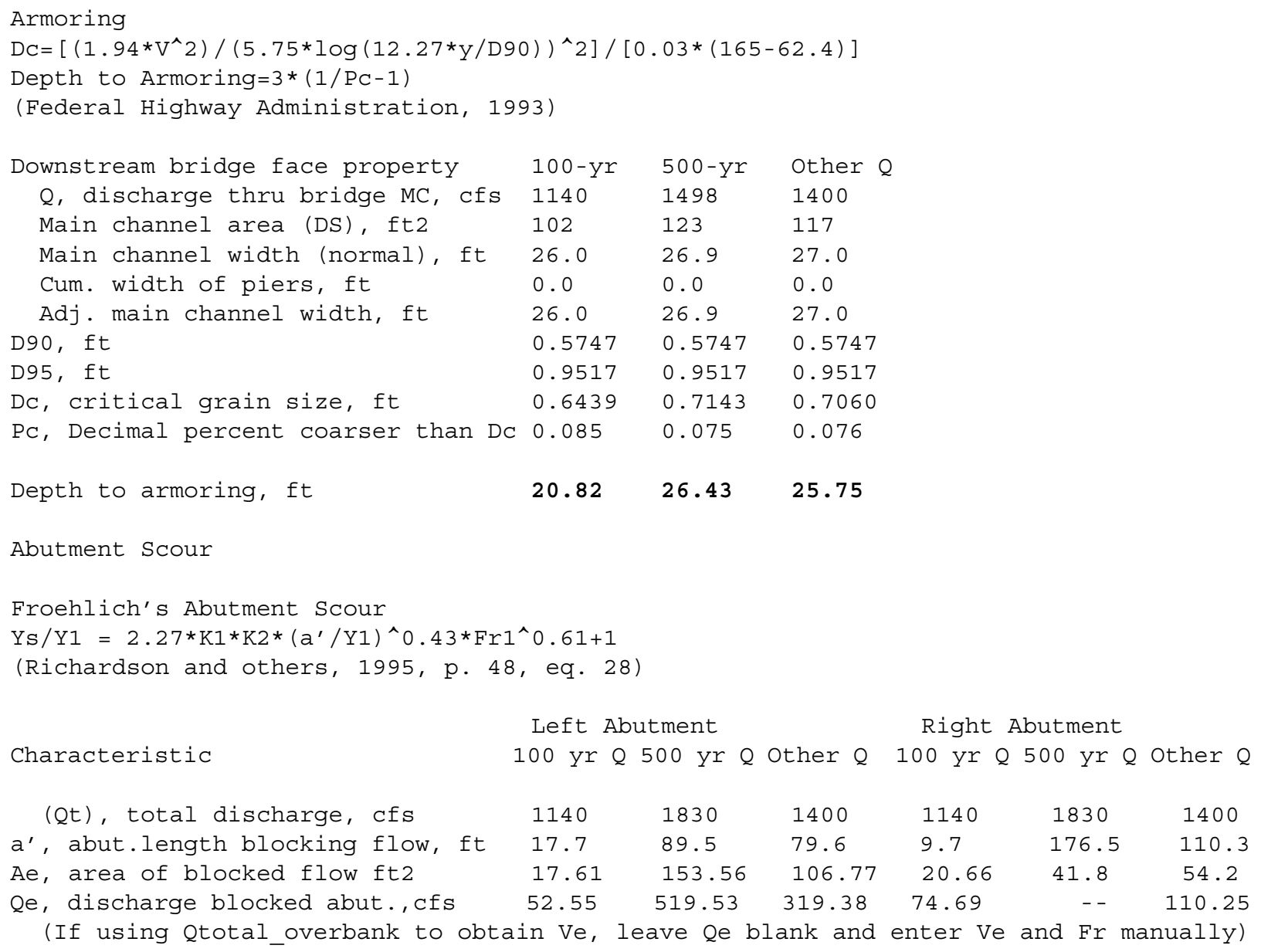




\begin{tabular}{|c|c|c|c|c|c|c|}
\hline Ve, $(\mathrm{Qe} / \mathrm{Ae}), \mathrm{ft} / \mathrm{s}$ & 2.98 & 3.38 & 2.99 & 3.62 & 1.84 & 2.03 \\
\hline ya, depth of $\mathrm{f} / \mathrm{p}$ flow, ft & 0.99 & 1.72 & 1.34 & 2.13 & 0.24 & 0.49 \\
\hline --Coeff., K1, for abut. type (1.0, & verti.; & $0.82, \mathrm{v} \epsilon$ & rti. w/ wi & ngwall; & $0.55, \mathrm{spi}$ & 11thru) \\
\hline $\mathrm{K} 1$ & 1 & 1 & 1 & 1 & 1 & 1 \\
\hline --Angle (theta) of embankment $(<90$ & if abut. & points & $\mathrm{DS} ;>90$ if & abut. & points US) & \\
\hline theta & 85 & 85 & 85 & 95 & 95 & 95 \\
\hline K2 & 0.99 & 0.99 & 0.99 & 1.01 & 1.01 & 1.01 \\
\hline Fr, froude number $\mathrm{f} / \mathrm{p}$ flow & 0.527 & 0.455 & 0.455 & 0.437 & 0.365 & 0.511 \\
\hline ys, scour depth, ft & 6.23 & 14.81 & 12.16 & 7.77 & 5.27 & 8.14 \\
\hline \multicolumn{7}{|c|}{$\begin{array}{l}\text { HIRE equation }\left(\mathrm{a}^{\prime} / \mathrm{ya}>25\right) \\
\mathrm{Ys}=4 \mathrm{Fr}^{\wedge} 0.33^{*} \mathrm{Y}{ }^{*} \mathrm{~K} / 0.55 \\
\text { (Richardson and others, 1995, p. 49, eq. 29) }\end{array}$} \\
\hline$a^{\prime}$ (abut length blocked, ft) & 17.7 & 89.5 & 79.6 & 9.7 & 176.5 & 110.3 \\
\hline y1 (depth f/p flow, ft) & 0.99 & 1.72 & 1.34 & 2.13 & 0.24 & 0.49 \\
\hline$a^{\prime} / y^{\prime}$ & 17.79 & 52.16 & 59.34 & 4.55 & 745.27 & 224.47 \\
\hline Skew correction (p. 49, fig. 16) & 0.98 & 0.98 & 0.98 & 1.01 & 1.01 & 1.01 \\
\hline Froude no. f/p flow & 0.53 & 0.46 & 0.46 & 0.44 & 0.37 & 0.51 \\
\hline \multirow{3}{*}{$\begin{array}{l}\text { Ys w/ corr. factor } \mathrm{Kl} / 0.55: \\
\text { vertical } \\
\text { vertical w/ ww's } \\
\text { spill-through }\end{array}$} & ERR & 9.46 & 7.40 & ERR & 1.25 & 2.90 \\
\hline & ERR & 7.76 & 6.06 & ERR & 1.02 & 2.37 \\
\hline & ERR & 5.20 & 4.07 & ERR & 0.69 & 1.59 \\
\hline \multicolumn{7}{|l|}{ Abutment riprap Sizing } \\
\hline \multicolumn{7}{|c|}{$\begin{array}{l}\text { Isbash Relationship } \\
\mathrm{D} 50=\mathrm{Y}^{\star} \mathrm{K} * \mathrm{Fr} r^{\wedge} 2 /(\mathrm{Ss}-1) \text { and } \mathrm{D} 50=\mathrm{Y} * \mathrm{~K} *(\mathrm{Fr} \wedge 2)^{\wedge} 0.14 /(\mathrm{Ss}-1) \\
\text { (Richardson and others, 1995, p112, eq. 81,82) }\end{array}$} \\
\hline Characteristic & Q100 & Q500 & Other $\mathrm{Q}$ & Q100 & Q500 & Other $\mathrm{Q}$ \\
\hline Fr, Froude Number & 1 & 1 & 1.01 & 1 & 1 & 1.01 \\
\hline y, depth of flow in bridge, ft & 3.91 & 4.57 & 4.33 & 3.91 & 4.57 & 4.33 \\
\hline Median Stone Diameter for riprap a & $t:$ left a & butment & & right & abutment, & ft \\
\hline Fr<=0.8 (vertical abut.) & ERR & ERR & ERR & ERR & ERR & ERR \\
\hline Fr>0.8 (vertical abut.) & 1.64 & 1.91 & 1.82 & 1.64 & 1.91 & 1.82 \\
\hline
\end{tabular}


